\title{
Ophioglossaceae (Psilotopsida) in Ukraine
}

\author{
Ivan Parnikoza ${ }^{1,2^{*}}$, Maria Chernyshenko ${ }^{3} \&$ Zbigniew Celka ${ }^{4}$
}

\author{
${ }^{1}$ Institute of Molecular Biology and Genetics, National Academy of Sciences of Ukraine, Acad. Zabolotnogo 150, Kyiv, 03143, Ukraine \\ ${ }^{2}$ National Historical and Architectural Museum Kyiv Fortress, Hospitalna 24A, Kyiv, 01133, Ukraine \\ ${ }^{3}$ M. G. Kholodny Institute of Botany, National Academy of Sciences of Ukraine, Tereschenkivska 2, Kyiv, 01004, Ukraine \\ ${ }^{4}$ Department of Plant Taxonomy, Faculty of Biology, Adam Mickiewicz University in Poznań, Umultowska, 89, 61-614 Poznań, Poland \\ *corresponding author (e-mail: i.yu.parnikoza@imbg.org.ua)
}

\begin{abstract}
The paper considers current ranges, population dynamics, habitats, threats and conservation measures of Ophioglossaceae of the Ukrainian flora. Only one specimen of Botrychium simplex was discovered in herbarium at the begining of the $19^{\text {th }}$ century. Taxonomical status of Ophioglossum azoricum in Ukraine needs additional studies. Other species of the family remain rare in Ukraine; there are only two reliable current localities of B. virginianum, and seven of $B$. matricariifolium. The number of B. multifidum, B. lunaria and Ophioglossum vulgatum localities have been decreasing since 1980 in comparison with the previous period, especially in the lowland part of the country. This tendency is accompanied by a very low stability of well-known populations - only some of them have been occurring from before 1980 up to modern times. Current conservation of Ophioglossaceae species in the protected areas is insufficient; it is necessary to create some new and enlarge some of the existing nature protection areas and include Botrychium simplex and Ophioglossum vulgatum in the Red Data Book of Ukraine.
\end{abstract}

Key words: Ophioglossum, Botrychium, Ukraine, range, population state, threat, conservation, review of literature, herbarium review

\section{Introduction}

Representatives of the Ophioglossaceae family have many characteristics that differ them from other ferns and are now considered to be Psilotaceae of Psilotopsida (Pryer et al. 2004; Smith et al. 2006). Although Ophioglossaceae are indisputably both rare and threatened in Europe as a whole (among others Procházka 2001, Witkowski et al. 2003; Rašomavičius 2007; Didukh 2009; Bilz et al. 2011; Grulich 2012; Kaźmierczakowa et al. 2014, 2016; García Criado et al. 2017), we still know too little about ranges, ecological specifics, as well as population biology of these ferns (e.g., Chadde \& Kudray 2001; Gilman 2003; Anderson 2005; Parnikoza \& Cukanova 2005; Melnik 2009; Olejnik \& Celka 2015). So detail studies in individual countries are very important to obtain a general picture of this taxon in Europe.

Presently, five Botrychium species: B. lunaria (L.) Sw., B. matricariifolium (Retz.) A. Braun ex W. D. J. Koch, B. multifidum (S. G. Gmel.) Rupr., B. simplex E. Hitchc. and $B$. virginianum (L.). Sw., and one representative of the genus Ophioglossum L. - O. vulgatum L. (Prokudin et al. 1999; Mosyakin \& Fedoronchuk 1999;
Didukh 2000; Parnikoza 2010; Vasheka \& Bezsmertna 2012; Parnikoza \& Celka 2016a, 2016b) occur in Ukraine. All species belong to the endangered taxa of the Ukrainian flora (e.g., Didukh 2009; Parnikoza \& Celka 2016a).

Oldest notes about Ophioglossaceae from Ukraine come from the beginning of the $19^{\text {th }}$ century. For instance, W. Besser (1822) reported B. lunaria and O. vulgatum from the area of Volhynia, Podilia and Kyiv Gubernia. The oldest Ophioglossaceae herbarium specimens originating from the Ukraine territory (Eastern part) were collected by Vasyl M. Chernaiev at the begining of the $19^{\text {th }}$ century (Parnikoza \& Celka 2016a, 2016b). I. Schmalhausen (1891), in addition to the species mentioned above, also cites $B$. multifidum and $B$. virginianum from the area of modern Ukraine (Melnik 2009). Rich collection was provided also from the Northern Ukraine by V. Montresor $(1891, \mathrm{KW})$. Some samples were collected in this period also by V. Kazanovsky, P. Rogovich, S. Vasiliev-Yakovlev, I. Selegynsky and others. The collection of Ophioglossasceae species of Eastern Ukraine was continued by G. Shyriaev, V. Taliev (see Taliev 1913) and K. Ugrynsky. For the Crimea, information was provided by I. Vankov, 
E. Wulff and V. Finn at the begining of the $20^{\text {th }}$ century. In the Western Ukraine herbariums, there are also some speciemens collected by Polish investigators: B. Blocki, T. Ciesielski and J. Lobarżewski. In the following period of 1920-30, for main part of Ukraine, collections were organized by Yu. Semenkevich, D. Zerov, A. Barbarych and F. Grin, V. Trahshel and others. In the same period, in this part of Ukraine, the first general descripton of the family Ophioglossaceae in Ukraine was published in the volume 1 of the Flora USSR (Fomin 1938). This source presents information about $B$. lunaria, $B$. multifidum, $B$. virginianum and $O$. vulgatum. In the $1930^{\text {th }}$, the detailed information about the spread of Ophioglossaceae in Bukovina was provided by Romanian botanist E. Țopa (Tokariuk 2005; CHER) and for Galicia (mainly modern Lviv, Ivano-Frankivsk and Ternopil oblasts) - by Polish botanists: J. Mądalski A. Szczawiński J. Motyka and W. Kędzierski (see specimens in KW, LW, LWS). They recorded for the first time $B$. matricariifolium in the Ukraine territory. In this period, there were also collected the data for the Ukrainian Carpathians by an Ukrainian scientist G. Kozij (see speciemns in LWS). After the Second World War, before the $1980^{\text {th }}$, some new Ophioglossaceae herbarium collections originating from the whole modern Ukraine, esspecially from the western part of the country, were provided by V. Komendar, O. Berko, M. Tzvelov, S. Kharkievich, S. Shelest, O. Krys, I. Artemchuk and others. In the $1980^{\text {th }}$, new information about Ophioglossaceae taxa, was collected mainly in the central and western part of the country by B. Geltman, M. Bortniak, V. Chopik, I. Vainagy, V. Melnik, L. Tasenkevich, Y. Kardash, A. Malinovski and others. Samples from the Crimea in this period were provided by V. Kosych, V. Korzenevsky and others (see specimens of YALT). The majority of data collected in all previous periods referred mainly to the records of Ophioglossaceae localities with the general description of biotops. More general description was provided in the identification key of vascular plants of Ukraine, edited by Prokudin et al. (1987, 1999). In 1996, there was also published the first edition of the Red Data Book of Ukraine, with the brief summarization about $B$. lunaria only. Very brief information about Ukrainian species of Ophioglossaceae was also included in the Volume 1 of the Ukrainian Ecoflora (Didukh 2000). Additionly, in the 1990-2000, along with the registration of our findings, a few papers were prepared that attempted the data generalization for several species, including the record number dynamics for some Ukrainian regions (Chorney et al. 2004; Tokariuk 2005) and, subsequently, for the whole country (Melnik 2009; Parnikoza 2010). This generalization partially summarized four species description in the second edition of the Red Data Book of Ukraine (Didukh 2009). Some studies that focused on the Ophioglossaceae population dynamics or details of population habitats and characteristics were conducted (Parnikoza 2002, 2012; Chornous 2005; Parnikoza \& Cukanova 2005; Bezsmertna \& Heluta 2013; Votkalchuk et al. 2014; Moysiyenko et al. 2016). Until now, there has been no modern generalization of information about $O$. vulgatum for the whole Ukraine. Thus authors of this review also tried to collect information about all Ukrainian Ophioglossaceae species records in one archive (Parnikoza \& Celka 2016a). Finally, in 2016, a new species for the Ukrainian flora $-B$. simplex, was discovered in KW herbarium (Parnikoza \& Celka 2016b). Thus, it is currently important to publish in English available information about the Ophioglossaceae family in Ukraine (the biggest European country after the European part of Russia), especially concerning the threats and conservation measures in the different regions of Ukraine. Today, all these facets are of crucial importance, in order to compile a thorough, critical review of current conservation status of these highly vulnerable ferns, and to develop a viable approach to improve their situation. It is important for Ukraine and for the whole European managment of these rare fern taxa. Hence, we aimed to prepare a review on the current status of all Ophioglossaceae species of Ukraine, including: general ranges, dynamics of the number of populations and their characteristics, habitat characteristics, threats and conservation recommendations.

\section{Materials and methods}

This article was based on available publications, beginning with collections dating back to the $19^{\text {th }}$ century (cf References). To analyse the current and historical distribution of Ophioglossaceae in Ukraine we used data from herbaria listed in Table 1. All collections have been checked by the authors.

The change in the amount of known species records was taken as a putative measure of dynamics in the population number. To characterize the current status of the species, we included only the articles or herbarium specimens dated after 1980. Even nowadays, the reports usually contain only the name of collector, time of the collection, name of the locality where a species was found and, but seldom, a scanty description of the location. Phytosociological relevés and demographic descriptions (the number and structure of populations) are even rarer. The lack of data makes drawing conclusions about the variety of these fern habitats and ecological amplitude possible only if all pieces of knowledge about individual sites, collected in the last 190 years, are combined and the results compared to the relevant data from neighbouring countries. Finally, it is very important to plan the study approach to Ophioglossaceae species in the future and their protection in Ukraine. We 
Table 1. List of herbaria used in research

\begin{tabular}{rll}
\hline No & The name of the herbarium & Acronym \\
\hline 1 & National Herbarium of Ukraine in the M. G. Kholodny Institute of Botany of National & KW \\
& Academy of Sciences of Ukraine in Kyiv & LW \\
2 & Ivan Franko National University of Lviv & LWKS \\
3 & Institute of Ecology of the Carpathians NAS of Ukraine, Lviv & LWS \\
4 & State Museum of Natural History of NAS of Ukraine, Lviv & KWU \\
5 & Taras Shevchenko National University of Kyiv & KWHU \\
6 & O. V. Fomin Botanical Garden of National Taras Schevchenko, National University of Kyiv & KWU \\
7 & M. M. Gryshko National Botanical Garden in Kyiv & KWHA \\
8 & Ukrainian National Academy of Sciences in Kyiv & MSUD \\
9 & Odessa I. I. Mechnikov National University & CHER \\
10 & Yu. Fedkowich National University of Chernivtsy & CWU \\
11 & V. N. Karazin National Univeristy of Kharkiv & DNZ \\
12 & Herbarium of Donetsk Botanical Garden of National Academy of Sciences of Ukraine & YALT \\
13 & State Nikita Botanical Gardens, Yalta & LE \\
14 & Komarov Botanical Institute of Russian Academy of Sciences in Saint Petersburg & \\
\hline
\end{tabular}

drew some generalizations about the threats to these species and looked at how well they are protected within the special protection areas (SPAs), and then tried to outline the measures that would ameliorate their conditions (partly, by a different form of conservation and establishing new SPAs). The detailed list of recomended SPAs was prepared for each Ophioglossaceae species as the first stage of creation of Emerald/Natura 2000 sites, as practical realization of the Bern convention in Ukraine (as part of the EU integration process). This article follows an original Ukrainian terminology of nature protection areas types: zapovednik - corresponds to IUCN Category Ia, i.e., a strict nature reserve, while zakaznik - corresponds to IUCN Category IV, i.e., habitat or species management area.

\section{Results}

\subsection{Ophioglossaceae in fossil materials from Ukraine}

The ferns of adder's-tongue family (Ophioglossaceae) are ancient components of flora of Ukraine. In particular, the representatives of the genera Ophioglossum and Ophioglossumsporites are known from the ValanginianAlbian deposits (131-100 Ma). In particular, there were such species as Ophioglossum porosum Bolch., Ophioglossum delectus Bolch. and Ophioglossumsporites multifoveolatum (Dor) M. Voronova. The spores of these species spread together with representatives of the presently known species of Selaginella and other Lycopodiaceae, as well as ferns of the genus Polypodium and Pteris, known in the modern Ukrainian flora (Voronova 1994).

The first records of modern european Ophioglossaceae species for Ukraine known from the Upper (Late)
Pleistocene - Botrychium boreale Milde (not present in the modern Ukrainian flora). B. virginianum is known from Allerød oscillation (AL, c.13,900 to 12,900 BP), while $B$. simplex - from the Younger Dryas (c. 12,900 to c. 11,700 BP). Also B. boreale, B. multifidum, and B. lunaria are known from Allerød oscillation to the Younger Dryas (DR-3). O. vulgatum occurred in a small number at the end of the last glacial period (AL, DR-3) in the forest zone of the modern eastern regions of Ukraine (Bezusko et al. 2011). The last information is very important, as it can explain the fact of the largest number of modern Ophioglossaceae populations in Ukraine in highlands (Parnikoza \& Celka 2016a), which probably corresponds to the ecological optimum for adder's-tongue family species (presumably relict), similarly like in the near-ice zone in the late-glaciation times.

Under the conditions of climate change and phytocoenotic circumstances during the Würm, eutrophic cold-loving species were expected to flourish, but at the modern time they retreated to a limited number of biotops with reduced competition, mainly in the mountainous or other areas with optimal temperature regime. For instance Botrychium lunaria was found in Carpinus betulus L. forests (Shevchyk et al. 1996) describe, where this species is common at the edges of ravines and on their northern slopes.

\subsection{General distribution and the number of populations}

Botrychium lunaria (common moonwort; Fig. 1A) is a pluriregional element of Ukrainian flora with a cosmopolitan range (Melnik 2000). In general, it is the most widely distributed moonwort, growing throughout the Northern Hemisphere across Eurasia and from Alaska to Greenland, as well as parts of the Southern Hemisphere, 

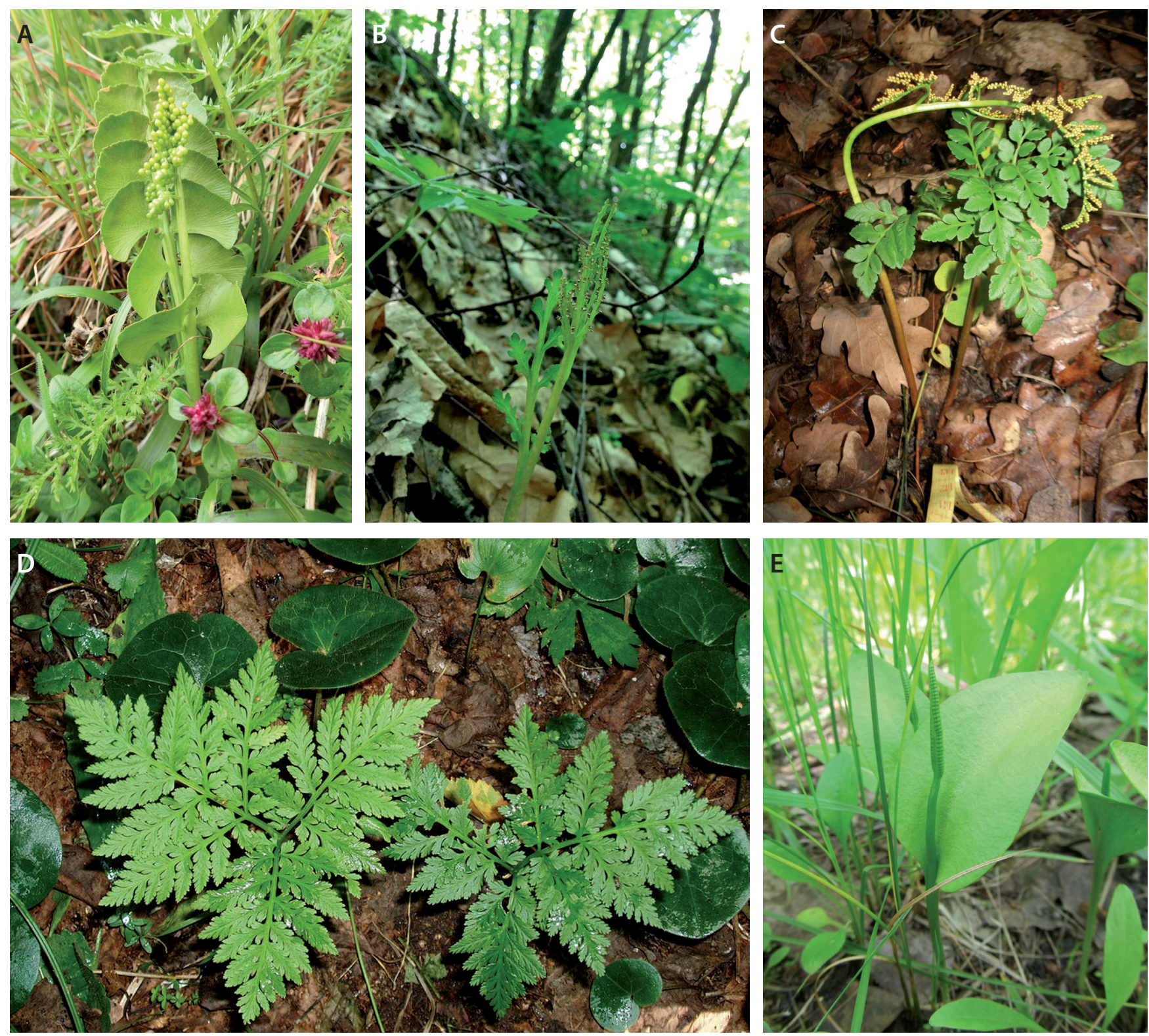

Fig. 1. Ophioglossaceae representatives in the flora of Ukraine

Explanations: A - Botrychium lunaria (subalpine meadow, SE slope of Shpycy Mt. Chornogora ridge, $1835 \mathrm{~m}$ a.s.1., 2016, photograph by R. Cherepanyn), B - B. matricariifolium (birch patch in beech forest, Antalovecka Polana Mt., Vihorlat-Gutin Ridge, $850 \mathrm{~m}$ a.s.l., 2016, photograph by V. Loya), C - B. multifidum (deciduous forest, Trukhaniv Island, Kyiv, 2012, photograph by I. Parnikoza), D - B. virginianum (damp deciduous forest, Pushkarivske Tract, Uglova Rudnia Village, 2009, photograph by O. Rak), E - Ophioglossum vulgatum (flood plain meadow, Uda river, Kharkiv, 2016, photograph by Yu. Bengus)

including New Zealand, Australia and South America (Meusel et al. 1965; Hultén \& Fries 1986; Wagner \& Wagner 1993). It is the only Ukrainian species that is found in the Arctic (Meusel et al. 1965; Hultén \& Fries 1986; Parnikoza 2015). B. lunaria is also the most common Botrychium species in Ukraine. Before 1980, it was known in Ukraine from 118 sites in 19 regions (Table 2, Fig. 2), thus, the main part of its range was situated in the western part of the country (Belgard 1938; Fomin 1938; Barbarych 1955; Chopyk et al. 1988; Voytyuk et al. 1991; Melnik 2000, 2009; Kucherevski 2001; Orlov et al. 2001; Parnikoza unpubl. 2001, 2008; Parnikoza \& Hilchuk 2002; Orlov \& Yakushenko 2005; Kuzminska 2006). After 1980, there are 58 populations in 12 re- gions registred (Table 2). Only 13 populations that had occurred before 1980 were confirmed after 1980. This is the biggest value of this parameter for all Ukrainian Ophioglossaceae species.

Botrychium matricariifolium (chamomile grapefern; Fig. 1B) is a holoarctic element of Ukrainian flora with European-North-American, disjunctive range which includes Scandinavia, Atlantic, Central and East Europe, North America with some exclaves in Asia (Meusel et al. 1965; Hultén \& Fries 1986; Wagner \& Wagner 1993; Melnik 2000). It was proposed (Tzvelev 2004,2005 ) that this species originated by hybridization of B. multifidum with B. lunaria (Melnik 2009). Its Ukrainian localities occur near the Southern border of its 


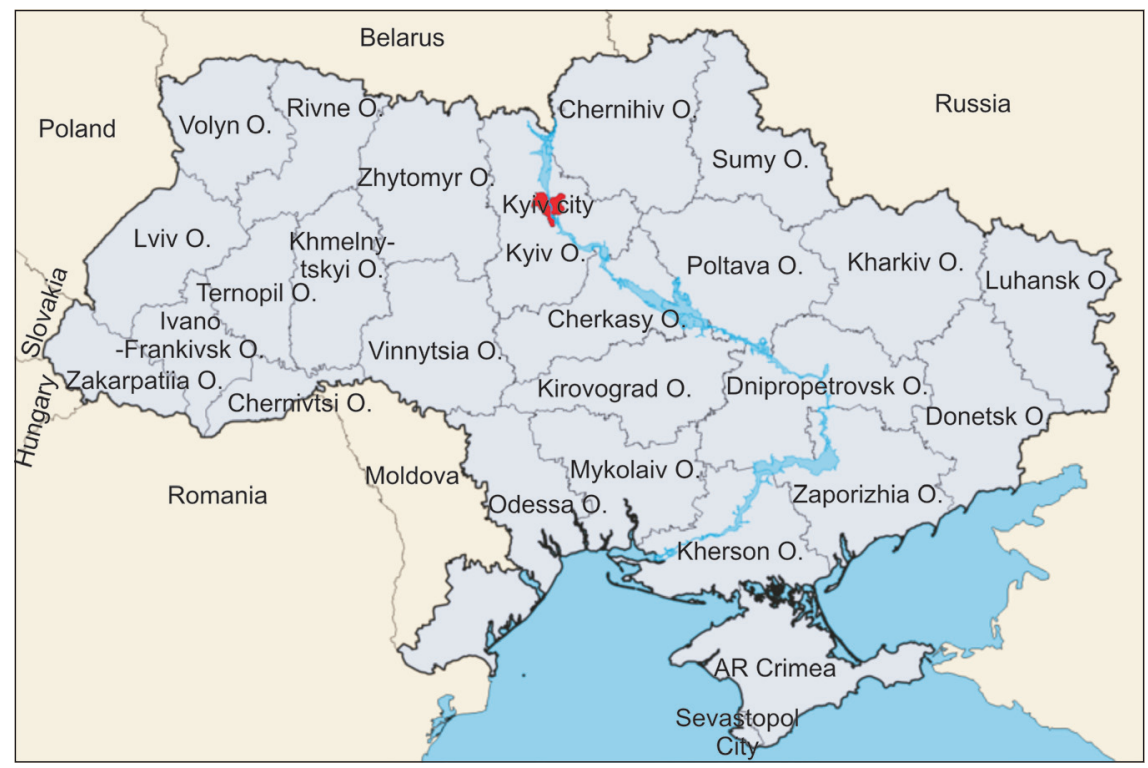

Fig. 2. Regions of Ukraine (based on the maps from https://commons.wikimedia.org/wiki/File:Map_of_Ukraine_political_simple_city_Kiew.png) Explantion: see Table 2

range (Melnik 2009). Before 1980, B. matricariifolium was known from 10 localiteis in 5 regions (Table 2, Fig. 2), but after 1980, there are only 7 localities in 5 regions of the western-middle part of the country (KW; Fodor 1974; Melnik 2000; Parnikoza 2002). No populations that existed before 1980 were confirmed letter.

Table 2. Number of Ophioglossaceae species localities in different regions of Ukraine

\begin{tabular}{|c|c|c|c|c|c|c|}
\hline Name of regions & B. 1. & B. ma. & B. mu. & B. s. & B. v. & O. v. \\
\hline AR Crimea & $20-2-1$ & $0-0-0$ & $0-0-0$ & $0-0-0$ & $0-0-0$ & $34-6-2$ \\
\hline Cherkasy O. & $1-1-2$ & $0-1-0$ & $1-0-0$ & $0-0-0$ & $0-0-0$ & $1-4-1$ \\
\hline Chernihiv O. & $3-1-0$ & $0-0-0$ & $5-2-0$ & $0-0-0$ & $1-2-0$ & $8-10-0$ \\
\hline Chernivtsi O. & $14-11-4$ & $0-1-0$ & $0-2-0$ & $0-0-0$ & $5-0-0$ & $34-7-4$ \\
\hline Dnipropetrovsk O. & $2-0-0$ & $0-0-0$ & $0-0-0$ & $0-0-0$ & $0-0-0$ & $0-5-0$ \\
\hline Donetsk O. & $0-0-0$ & $0-0-0$ & $0-0-0$ & $0-0-0$ & $0-0-0$ & $0-0-0$ \\
\hline Ivano-Frankivsk O. & $15-8-3$ & $1-1-0$ & $2-5-1$ & $0-0-0$ & $0-0-0$ & $6-4-0$ \\
\hline Kirovograd O. & $2-0-0$ & $0-0-0$ & $0-0-0$ & $0-0-0$ & $0-0-0$ & $0-0-0$ \\
\hline Kharkiv O. & $11-3-0$ & $0-0-0$ & $8-1-0$ & $1-0-0$ & $5-0-0$ & $10-2-0$ \\
\hline Kherson O. & $0-0-0$ & $0-0-0$ & $1-0-0$ & $0-0-0$ & $0-0-0$ & $1-4-1$ \\
\hline Khmelnytskyi O. & $1-1-0$ & $0-0-0$ & $0-0-0$ & $0-0-0$ & $1-0-0$ & $4-0-0$ \\
\hline Kyiv city & $2-0-0$ & $0-0-0$ & $4-6-0$ & $0-0-0$ & $1-0-0$ & $6-12-0$ \\
\hline Kyiv O. & $1-1-0$ & $0-0-0$ & $2-3-0$ & $0-0-0$ & $0-0-0$ & $5-7-0$ \\
\hline Luhansk O. & $0-0-0$ & $0-0-0$ & $0-0-0$ & $0-0-0$ & $0-0-0$ & $5-2-0$ \\
\hline Lviv O. & $7-7-0$ & $3-0-0$ & $10-1-0$ & $0-0-0$ & $7-0-0$ & $11-8-0$ \\
\hline Mykolaiv O. & $0-0-0$ & $0-0-0$ & $0-0-0$ & $0-0-0$ & $0-0-0$ & $0-1-0$ \\
\hline Odessa O. & $0-0-0$ & $0-0-0$ & $0-0-0$ & $0-0-0$ & $0-0-0$ & $0-0-0$ \\
\hline Poltava O. & $6-0-0$ & $0-0-0$ & $0-0-0$ & $0-0-0$ & $0-0-0$ & $10-3-0$ \\
\hline Rivne O. & $1-0-0$ & $0-0-0$ & $4-0-0$ & $0-0-0$ & $2-0-0$ & $0-1-0$ \\
\hline Sevastopol City & $0-0-0$ & $0-0-0$ & $0-0-0$ & $0-0-0$ & $0-0-0$ & $1-4-0$ \\
\hline Sumy O. & $2-0-0$ & $0-0-0$ & $4-6-0$ & $0-0-0$ & $0-0-0$ & $1-5-0$ \\
\hline Ternopil O. & $0-2-0$ & $1-0-0$ & $1-1-0$ & $0-0-0$ & $1-0-0$ & $2-3-0$ \\
\hline Vinnytsia $\mathrm{O}$. & $1-0-0$ & $1-0-0$ & $0-0-0$ & $0-0-0$ & $0-0-0$ & $3-0-0$ \\
\hline Volyn O. & $1-0-0$ & $0-1-0$ & $1-3-0$ & $0-0-0$ & $0-0-0$ & $1-10-0$ \\
\hline Zakarpatiia O. & $23-19-3$ & $4-3-0$ & $3-1-0$ & $0-0-0$ & $1-0-0$ & $4-20-0$ \\
\hline Zaporizhia O. & $0-0-0$ & $0-0-0$ & $0-0-0$ & $0-0-0$ & $0-0-0$ & $2-0-0$ \\
\hline Zhytomyr O. & $5-2-0$ & $0-0-0$ & $8-0-0$ & $0-0-0$ & $0-0-0$ & $6-2-0$ \\
\hline Total & $118-58-13$ & $10-7-0$ & $54-31-1$ & $1-0-0$ & $24-2-0$ & $152-120-8$ \\
\hline
\end{tabular}

Explanations: B. 1. - Botrychium lunaria, B. m. - B. matricariifolium, B. mu. - B. multifidum, B. s. - B. simplex, B. v. - B. virginianum, O. v. - Ophioglossum vulgatum; the number of: archival localities before 1980, modern localities recorded after 1980, localities that existed before 1980 and confirmed later; O-Oblast 
Botrychium multifidum (leathery grapefern; Fig. 1C), a pluriregional element of Ukrainian flora with cosmopolitan range (Melnik 2000). In general have a disjunctive distribution in Europe, Asia and North America (Meusel et al. 1965; Hultén \& Fries 1986; Wagner \& Wagner 1993; Anderson 2005). In Europe, the western border of its range runs through Germany, Eastern France and Northern Italy, the southern border - from Northern Italy through Austria, northern part of Serbia, Hungary, Ukraine and Central Russia (Melnik 2009; Szczęśniak et al. 2014). B. multifidum in Ukraine is near its southern limit. It is found at Volhynia and Small Polesia, rarer in the Carpathians and in ForestSteppe zone (Bezsmertna \& Heluta 2013). It has been found in Ukraine before 1980 in 54 sites in 14 regions (Table 2, Fig. 2). Since 1980, it is known from 31 localities in 11 regions, mainly in the western part of the country. (KW; Fomin 1938; Didukh \& Protopopova 2000a; Melnik 1976, 2000; Panchenko 2005; Parnikoza \& Cukanova 2005; Klimuk et al. 2006; Andrienko et al. 2007; Andrienko 2009; Bezsmertna \& Heluta 2013). Only one population out of those that existed before 1980 was confirmed in modern times.

Botrychium simplex (least moonwort) has an amphiatlantic distribution. This species was known in Europe from Finland to Corsica and Pyrenees, numerous localities were noted in Poland and Germany, but, presently, it is occurring mainly in Iceland, Southern Greenland, North America and Japan (Meusel et al. 1965; Hultén \& Fries 1986; Wagner \& Wagner 1993; Żukowski et al. 2014).The species has not been reported from Ukraine (Mosyakin \& Fedoronchuk 1999). One herbarium specimen corresponding to the characteristics of $B$. simplex, collected by V. Chernaiev on June 12, 1828 in Kharkiv, was found in herbarium KW (Table 2, Fig. 2). This locality of $B$. simplex was completely transformed due to human activities (Parnikoza \& Celka 2016b).

Botrychium virginianum (rattlesnake fern; Fig. 1D) is a boreal element of the flora of Ukraine with a boreal range; it has a cosmopolitan disjunctive distribution and can be found almost on every continent (Chadde $\&$ Kudray 2001; Melnik 2000). Rattlesnake fern grows in North and South America, in Eurasia it is spread from the Alps in Europe to the Amur mouth in the Far East (Hultén \& Fries 1986; Wagner \& Wagner 1993). In Siberia, it is found only south of $60^{\circ}$ N.L. It occurs also in some parts of India, China, Australia and New Zeland. The European part of its range includes Alps, the Carpathians, Fennoscandia, Caucasus and European part of Russia, Ukraine, Belarus and Poland (Melnik 2009). In the past, before 1980, it was reported from 24 locations in 9 regions (Table 2, Fig. 2). However, currently it has been confirmed only in 2 localities in Chernihiv oblast: near the villages Uglova Rudnia and Zubachy in Rypkynsky District (KW; Schmalhausen
1897; Mądalski 1938; Motyka 1947; Melnik 2000; Melnik et al. 2006). No populations that existed before 1980 have been confirmed im modern times.

Ophioglossum vulgatum (adder`s-tongue; Fig. 1E) is a holoarctic element of the flora of Ukraine (Kucherevski 2001). Its general range includes Scandinavia, Central, Atlantic and Eastern Europe, Mediterranean, Caucasus, Ural, Siberia, Middle Asia, Iran, Japan, North-West part of Africa, North and South America (Meusel et al. 1965; Hultén \& Fries 1986; Wagner \& Wagner 1993; Vasheka \& Bezsmertna 2012; www.floraargentina.edu. ar). In Ukraine, before 1980, it was found in 152 sites in 21 regions (Table 2, Fig. 2). After 1980, there were 120 populations known from 21 regions (KW; Fomin 1938; Sheleheda \& Rastvorova 2007; Tokariuk 2005). Only 8 populations that existed before 1980 have been confirmed in modern times (after 1980).

Among the specimens of Ophioglossum vulgatum there are some with the features of $O$. azoricum C. Presl. Previously, this taxon was seen as a subspecies of $O$. vulgatum. This is a polyploid that originated from the crossing of $O$. vulgatum and $O$. lusitanicum $\mathrm{L}$. (Ceynowa-Giełdon 1999, 2001). Main features: leaves 2 (rarely 3 ), the trophophore blade up to $3.5 \mathrm{~cm}$ long and up to $1.7 \mathrm{~cm}$ in width, the sporophore with 6-15 sporangia. It is a rare species, occurring in Western Europe, where it has a dispersed distribution, in Portugal, France, Great Britain, Ireland and Iceland (Meusel et al. 1965; Jalas \& Suominen 1972; Dostál 1984; ww2. bgbm.org/EuroPlusMed). Its range partly overlaps with O. vulgatum. Distribution in central and eastern Europe requires further confirmation. In the case of Poland, there is also no certainty whether two-leaf and, as a rule, smaller specimens correspond to the taxa of O. azoricum. Howewer, to solve this problem, genetic research is needed (Ceynowa-Giełdon 1999, 2001). In Ukraine, specimens that correspond to the description given for O. azoricum were identified in 7 localities. Three of these localities were found before 1980 and three after 1980, one of them existed before 1980 and was confirmed after this time. However, individuals growing in sand due to environmental conditions may be smaller. Such small herbarium specimens (4-10 cm in length) were reported from Poland by Ceynowa-Giełdon (1999).

\subsection{Habitats}

It is difficult to assign the Ukrainian species of Ophioglossaceae to a certain type of habitat or vegetation community. The non-specific nature of Botrychium habitats in general has been noted in literature (Lellinger 1985). The common characteristic is some level of intermittent or past soil disturbance (Chadde \& Kudray 2001). Because these species show a wide variability depending on basic ecological factors, they occur in a diversity of vegetation types (Zarzycki et al. 2002; Didukh 2011). 

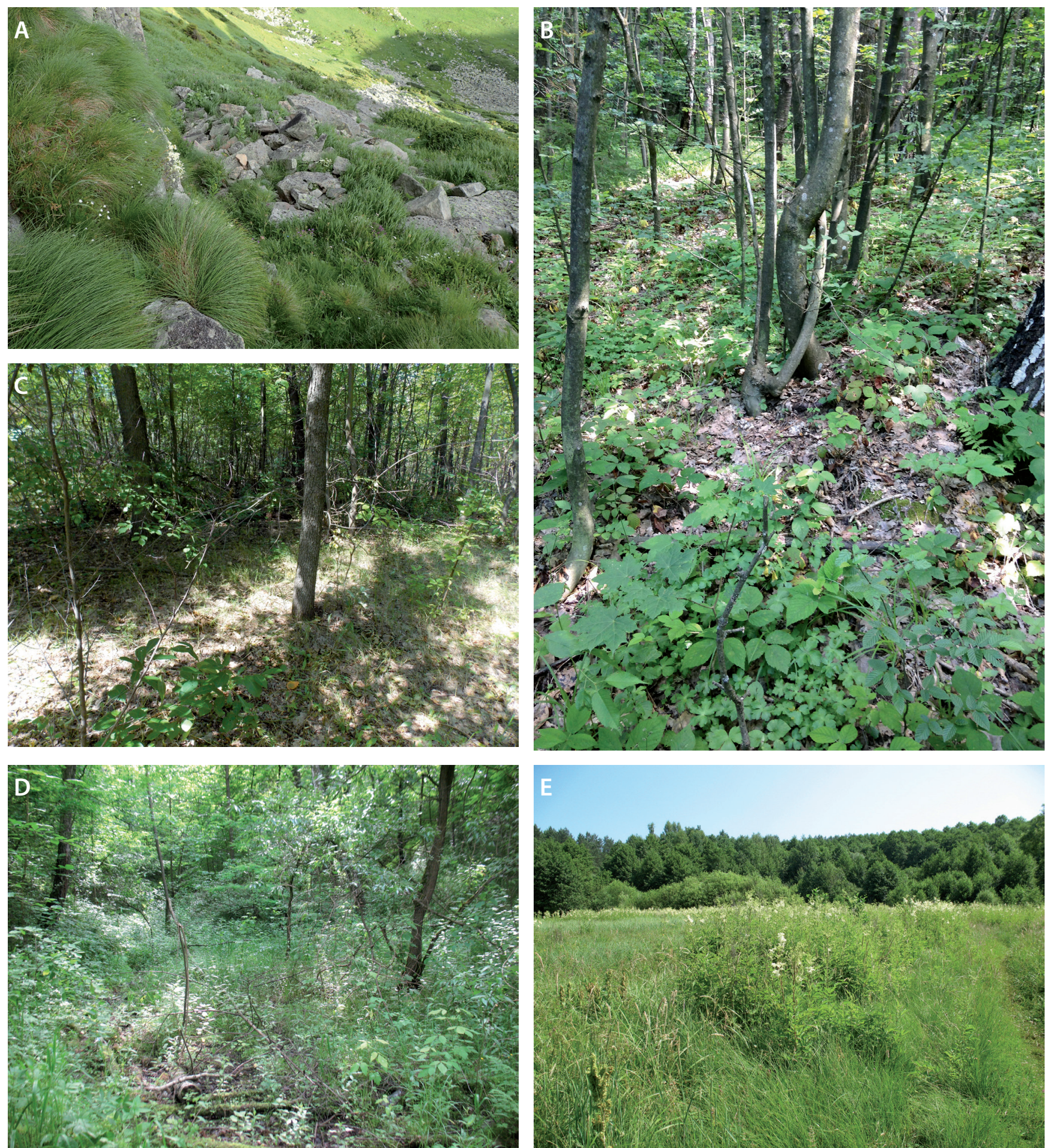

Fig. 3. Selected communities with the participation of species of the family Ophioglossaceae in the Ukraine

Explanations: A - Botrychium lunaria (subalpine meadow, SE slope of Shpycy Mt. Chornogora ridge, $1835 \mathrm{~m}$ a.s.1., 2016, photograph by R. Cherepanyn), B - B. matricariifolium (birch patch in beech forest, Antalovecka Polana mt., Vihorlat-Gutin Ridge, 2016, photograph by V. Loya), C - B. multifidum (deciduous forest, Trukhaniv Island, Kyiv, 2012, photograph by I. Parnikoza), D - Ophioglossum vulgatum (swamp ravine with deciduous forest, Vyshgorod, 2008, photograph by I. Parnikoza), E - O. vulgatum (rushes, Sviatoshyn ponds, 2007, photograph by I. Parnikoza)

It was noted that $B$. lunaria in term of habitat preferences is associated with the communities of MolinioArrhenatheretea (Arrhenatheretalia) and Nardo-Callunetea (Nardetalia) (Didukh \& Protopopova 2000b). Hovever, in Ukraine this most widespread moonwort known from different zones and different habitats: beech woods and regrowth forests with rich undergrowth, high-mountain meadows (Fig. 3A) and saxicolous communities of the Carpathians (Parnikoza unpubl. data 2001; Klimuk et al. 2006; Kuzminska 2006; Onyshchenko \& Andrienko 2012b), calcicolous forest stands of Podolia (Chubata \& Boyko 2003), lowland 
meadows of Polesia (KW; Bortnyak 1962; Andrienko et al. 2007), and deciduous forests of the Forest-Steppe Zone (KW; Fomin 1938; Shevchyk et al. 1996; Orlov et al. 2001; Andrienko pers. comm. 2006). It enters the Steppe Zone along rivers, where it grows on meadows in gramineous or moss coenoses of sandy floodplain terrains (Kucherevski 2001). Also, it was noted in the yaila (Crimean mountain valleys) meadows (Rubtsov 1972; Rudenko 2015).

In Western Europe, it grows primarily in sandy and Nardus-dominated grasslands, and pioneer communities, like alpine grasslands, especially on calcareous soils (Dostál 1984; Austrheim \& Olsson 1999; Muller 1999; Zarzycki et al. 2002; Piękoś-Mirkowa \& Mirek 2006). In France, it was observed in ViscarioAveneteum, V.-A. airetosum, V.-A. saxifragetosum, $V$.-A violetosum caninae and Aveno-Genistetum communities (Muller 1999). It is also a component of Molinia meadows (code 6410), protected in Europe within the Natura 2000 network (Council Directive 1992). In the North Slope of Alaska, B. lunaria prefers higher gravel sites with lower density of herbaceous plant cover and small shrubs (Parnikoza 2015). In New England (USA), it occurs in maritime grasslands along the coast of eastern Maine, northern white cedar forests in northern Maine, and possibly, in the forested hilltop areas of southeastern Vermont. Calcareous soils, derived either from bedrock, calcareous till deposits or from ongoing calcium deposition from ocean debris (i.e., mussel shells), or sea-spray are required for this species (Gilman 2003). The North American habitats of $B$. lunaria are grassy or mossy meadows and sandy or gravelly riverbanks. It grows in acid to circumneutral soils. In the Great Lakes region, open fields, and less often forests, are described as typical habitats. The National Plant Data Center listed a number of habitat characteristics for B. lunaria, including soil tolerance (no fine-textured soils), soil $\mathrm{pH}$ range (5.8 to 7.2), and minimum and maximum precipitation range. A Forest Service database described its habitats as cool/moist conditions, along forest roads and trails, in open areas, lakeshores (sand dunes), and occasionally in forests; plants were also reported from sandy soils of old log landings in jack and red pine woods. In Wisconsin, B. lunaria typically occurs in cool, moist sandy soils, under a boreal or northern hardwood forest cover. Another Wisconsin source reported that $B$. lunaria needs shade and may be found in cool, calcareous conditions, along moist, mossy and wooded streambanks and in ravines near Lakes Michigan and Superior. In Minnesota, B. lunaria appears to prefer open habitats, such as gravelly banks, rocky ledges, and taluses, but there are less than 10 occurrences reported for the state. In Michigan, most $B$. lunaria occurrences were in areas with limestone and dolomite close to the surface. Also, large populations were found in old fields (Chadde \& Kudray 2001).

B. matricariifolium was described as connected with Nardo-Callunetea (Nardetalia) communities (Didukh \& Protopopova 2000c). It was reported from the post-forest meadows of the Carpathians (Melnik 2000; Taseinkevich 2009; Votkalchuk et al. 2014), beech mountain forest (LW) Fig. 3B), beech-pine and hornbeam Podolia woodlands, pine lowland forest (Votkalchuk et al. 2014), and 140 years old Quercus-Carpinus forest in Tisza river valley (Kish et al. 2005). It was also found in the littoral zone of the Kaniv Reservoir, thoroughly overgrown by shrubs and trees (Parnikoza 2002). It was very sensitive to drought and in some years, it didn't vegetate long enough to produce spores (V. Shevchyk, pers. comm. 2008). Some species of Orchidaceae have been lost in this area in the last five years of succession, while B. matricariifolium wasn't observed since 2008 (Onyshchenko \& Andrienko 2012a).

Because of its rarity, it is likely that Ukrainian population do not represent a complete spectrum of $B$. matricariifolium environmental requirements. Thus, it is interesting to analyze information from other places in Europe. In Tver Oblast (Russia), it was found in humid forests and meadows (Notov 2002a). In Belarus, however, it grows in drier, broadleaf or coniferous forests and meadows not only within floodplains (Blazhevych \& Dzhus 2005). In Western Europe, this species was reported from open or slightly shaded communities of the order Nardetalia (grasslands with non-calcareous substrate). Seldom, it also occurs in the forest stands of the Dicrano-Pinion and the Quercion robori-petraeae alliances and in wet meadows of the order Molinietalia caeruleae (Oberdorfer 1994; Chrtkowá 1997; Braun 1999; Zarzycki et al. 2002). It prefers species-poor and somethimes nutrient-deficient swards. It occurs also in pastures and in glades, and in open forests. The species was noted on acid, sandy or clay soils (Nowak \& Nowak 2008). In Polish Silesia, B. matricariifolium grew at the edge of pine-oak and acid oak forest, at the edge of pine forest of Leucobryo-Pinetum type (Szczęśniak 1998; Bobrowicz et al. 2004), and in transitional meadow community (Nowak \& Nowak 2008). From Wielkopolska, it was reported mainly from woodlands: nemoral Carpinus betulus L., Betula pendula Roth., Fagus sylvatica L., Quercus robur L., Acer platanoides L., and Populus tremula L. forests (Celka \& Kasprowicz 2002; Czarna 2002; Gierczyk et al. 2007). In the Czech Republic and Slovakia, it was found on poor acidic substrata and non-calcium sands in pine, spruce and beech forests, but most often on meadows, near paths (Braun 1999). In France, this moonwort was observed in Diantho-Armerietum, Viscario-Aveneteum, V.-A. airetosum, $V$.-A. saxifragetosum, and $V .-A$ violetosum caninae communities (Muller 1999). 
B. matricariifolium is able to colonize new, substitution habitats in ecosystems altered by humans, which reflects its adaptive plasticity (Kujawa et al. 2005). In many places it appeared in the areas that have been ploughed and cultivated for several decades or in recently disturbed habitats, such as roadsides or forest path edges (Muller 1999). In some sites, it was noticed to be associated with introduced species, such as Padus serotina (Ehrh.) Borkh. (Celka \& Kasprowicz 2002).

B. multifidum has equally wide ecological amplitude. It is a characteristic species of Molinio-Arrhenatheretea and Nardo-Callunetea (Nardetalia) communities (Didukh \& Protopopova 2000a). It can grow in postforest meadows and in meadow communities that reach the subalpine zone. Probably in meadow habitats, the species is found in Sumy Oblast in zapovednik Mykhailivska tselyna (Tkachenko et al. 1998). Thus, besides meadows, this moonwort also grows in pine forests of different age, in patches with mosses, Betula pendula groves, Alnus glutinosa (L.) Gaerth. forests and bogs, edges of Sphagnum-peat bogs, in spontaneous forests of the Dnieper islands (Fig. 3C), spruce plantations, and in the central part of Prypyvat river floodplain (Parnikoza \& Cukanova 2005; Klimuk et al. 2006; Melnik 2009; Parnikoza \& Shevchenko 2009; Bezsmertna \& Heluta 2013). The species was also recorded in regrowth forests, for example, on former military training ground 3 km westwards of Volodymyr-Volynski (Melnik 2009). For the Steppe Zone of Ukraine, in the $19^{\text {th }}$ century, there was one report of the species occurrence in the vicinity of the village of Velyka Olexandrivka in Kherson Oblast (Melnik 2009).

In Belarus, B. multifidum is considered primarily boreal, but can be found also on Nardo-Callunetea meadows (Blazhevych 2005). In Poland, this species is known from acid soils, most often in semi-natural habitats on poor meadows, in Calluna vulgaris (L.) Hull. communities, and near field roads, rarer, in acid oak forests and mixed-pine forests. The species was observed mainly in Nardo-Callunetea communities and spontaneous communities at different stages of regeneration (Szczęśniak et al. 2014). In the upper part of Narew Valley, it was described from meadows and pastures in NardetoCallunetea comminities (Wołkowycki \& Pawlikowski 2008). In the Kujawy-Pomerania Voivodeship, it was found in spontaneous vegetation in the vicinity of a road in pine forest (Załuski \& Paszek 2002). In the Polish Carpathians (Tatra mountains and West Bieszczady), it spread in Hieracio-Nardetum community on disturbed meadows with ruderal species (Piękoś-Mirkowa et al. 2008). In Wielkopolska, it was found in mixed plantations of Acer platanoides (Celka \& Kasprowicz 2002). Thus, in Ukraine, Belarus, Poland and Russia, this moonwort tends to grow in semi-natural conditions, along cuttings and roads, on the edges of overgrown fields and on pastures, which points at a certain level of dependence on anthropogenic impact.

Within a continuous population, $B$. multifidum is able to spread across a number of habitats. This is true of practically all species of Botrychium. The best illustration of such habitat adaptability can be a transect passing from an open field into the edge of woods and then deep into the shade of the woods, where a given species is abundant (Wagner 1962).

B. simplex in Ukraine was collected only in the Kharkiv river valley on wet sandy places in the community of Juncus capitatus Weigel. (Parnikoza \& Celka 2016b). Information about its habitat preferences in Europe is also limited. In Poland, it was noted on acidic substrate, without calcium, usually near lakes. It is a component of Nardus stricta L. grasslands and Calluna vulgaris stands. Considered as a characteristic species of Calluno-Ulicetalia and Nardetalia orders. Observed with Calluna vulgaris, Danthonia decumbens DC., Festuca ovina L. and Agrostis capillaris L. Similar habitats are reported from Western Europe (Żukowski et al. 2014). In Belarus, it grows in dry and peat meadows (Parfienov 2009; M. Dzhus, pers. comm. 2014; Dubovik \& Lebiedko 2015).

B. virginianum in Ukraine is thought to be a boreal plant of meadows and wet woodlands (Melnik 2009). According to local data, it tends to grow in shadowy forests with limestone lying near the surface, or not far away from swamps. In Ukraine, the species is coenotically linked to Fagus sylvatica, Carpinus betulus, and Populus tremula-Betula pubescens forests (Melnik 2009), although, according to the Red Data Book of Ukraine, it is associated with Quercus spp., Quercus spp.-Fagus sylvatica, and Quercus-Carpinus betulus stands, where it prefers the forest edges (Kagalo \& Chorney 2009). Didukh \& Protopopova (2000d) describe it as an element of Nardo-Callunetea (Nardetalia) communities. It has been also noted in mountain regions (Chopyk et al. 1977, 1988; Malynovsky et al. 2002). However, this is probably a mistake, since this site is not supported by a herbarium specimen (Melnik 2009). The one site from two where it occurs nowadays is Populus tremula-Betula pubescens Ehrh. patch (Melnik et al. 2006; Melnik 2009).

Generally, this species can be found in a wide variety of plant communities. Thus, in Northern Europe (Sweden, Finland, Russia), it grows in spruce and pine forests, broad-leaved copses, bog edges, and forest peat bogs (Ståhl 1998; Notov 2002b; Parnikoza \& Krinitsyn 2014). In the Warmia-Masuria Voivodeship (Poland), it was found in broadleaf and mixed woods (among others, in the site near Olsztyn), as well as at the edges of such communities, preferring rich soils. In Belarus, it is considered a woodland-meadow species and occurs in 
spruce-broadleaf, linden, poplar, and birch forests with bracken, wood sorrel, goutweed, and more seldom - bilberry, near eutrophic, often spring-fed bogs. It prefers fresh, nutrient-rich soils and shadowed microhabitats and tends to be found in the least-disturbed woodlands (Blazhevych \& Dubovik 2005). The species can grow in both the least-disturbed, protected woodlands and regrowth forests, and, additionally, prefers places naturally disturbed or affected by people and grows along forest roads (Pawlikowski 2011; Parnikoza \& Krinitsyn 2014). According to our observation in Pennsilvania, US (2013), this species can grow also in secondary broadleaf forests in the places of total cutting in the past.

$O$. vulgatum also has a wide range of habitats. According to Didukh \& Protopopova (2000e), this species participates in Molinio-Arrhenatheretea, Molinieatalia, Molinion, Querco-Fagetea, DentarioFagetalia, Dentario quinquefoliae-Fagion sylvaticae, Carpinion betuli, Alnetea glutionsae, Alnetalia glutinosae, and Alnion glutinosae. In Ukraine, it can grow in two main habitats: meadow (Fig. 3D) and forest (Fig. 3E). In some cases, O. vulgatum can grow also along the edges of Sphagnum bogs and marshy depressions in the sandy pine-forest floodplain terraces (KW; Fomin 1938; Chopyk et al. 1998; Orlov et al. 2001; Pryadko 2004; Nakonechny 2007). According to Dmytrash-Vatseba (2018), it occurs in the Opillia region in Deschampsion caespitosae and Alopecurion pratensis communities. It was also recorded in the forest belt of the Carpathians, and in the mountain meadows of the Crimea as a rather rare species (Rubtsov 1972; Chopyk et al. 1977; Malynovsky et al. 2002; Vakhrusheva 2015). In Ukraine, it is also recorded in spontaneously-formed forests, as well as forests formed by introduced species, in particular, Robinia pseudoacacia L. (Parnikoza \& Celka 2016a).

According to Polish data, O. vulgatum is characteristic for Molinietalia caeruleae - wet mesotrophyc meadows flooded in some periods of the year (Matuszkiewicz 2001; Zarzycki et al. 2002). It is generally considered a grassland species, characteristic of the wet and oligotrophic Molinion caeruleae alliance, which can occasionally occur in the most mesotrophic AgropyroRumicon or Arrhenatherion plant communities. In France, O. vulgatum has been discovered in several hygrophylic oak-ash forests belonging to the Carpinion alliance. $O$. vulgatum is present in all stages of the forest cycle, but it is most abundant during the younger succession stages (Muller 2000). For Western Europe, it was noted that $O$. vulgatum prefers meadows and rarer grows in forests (Muller 2000). Probably this is connected with the general situation with wet forest ranges in this part of Europe. In Ukraine, this species may grow in forests in near-climax (stable) states, like on Diyvka floodplains, where it grows in a shaded Populus-Salix thicket (Maniuk, pers. comm., 2015). Similar sites were described in Kyiv (Parnikoza 2012). In Ukraine, this species is also known from semi-natural habitats like abandoned fishing ponds, margins of drainage channels or old apple orchards. In Russia, it is considered to grow mostly on meadows and forest glades with well-drained soils (Filin 1995).

Individuals that correspond to $O$. azoricum in Ukraine were found in melioration canals, in marshy birch and alder forest, among mosses. Also, they were noted in the wet depressions on sandy terraces of the rivers Mzha and Siverskyi Donets (Kharkiv Oblast) and on the Oleshkovsky Sands (Khersonska Oblast). In Poland, the species also grows on sand, on a thin layer of peat and on meadows and pastures, often together with $O$. vulgatum, and sometimes $B$. simplex (CeynowaGiełdon 1999, 2001). In Great Britain, it was observed in coastal areas, on peat and sand (Ceynowa-Giełdon 1999).

\subsection{Population characteristics}

B. lunaria has following onthogenesis stages: $\mathrm{J}$, $\mathrm{Im}, \mathrm{V}, \mathrm{Sp}_{1}, \mathrm{Sp}_{2}, \mathrm{Sp}_{1-3} \mathrm{~V}$ (Fig. 4). J - juvenile (the first premature stage) has a small aboveground tri-pinnately dissected leaf up to $1 \mathrm{~cm}$ in length, Im - immature (the second premature stage) has a five-pinnate leaf of approximately simmilar length, $\mathrm{V}$ - virginile (the third premature stage) has a lager leaf with three segments, the upper segment tri-dissected, $\mathrm{Sp}$ - mature reproductive stage has the sporophore $-\mathrm{a}$ fertile part of the leaf. Sp-individuals can be divided into: $\mathrm{Sp}_{1}$ - young sporophytes with sporangia on short branches of the sporophore, $\mathrm{Sp}_{2}$ - adult individuals with longer branches of the sporophore, whereas $\mathrm{Sp}_{1-3} \mathrm{~V}$ have an adult type of the trophophore and no sporophore, which is reduced to a small fragment on the surface of the stalk. There are also some cases of neoteny - the formation of sporophyll in pre-mature individuals and polyvariability of ontogenesis (Krinitsyn 2004; Parnikoza et al. 2008). In Ukrainian populations only Sp plants were registered. This was confirmed by observation by J. G. Krinitsyn from Russia, according to whom the registration of prereproductive stages for this fern is very rare (Krinitsyn 2008).

Little information is available about the population biology of $B$. lunaria. Population studies on other species of moonworts have shown that there can be considerable annual variation in the number of aboveground plants at a given site (Johnson-Groh 1998). This study also reported that populations fluctuated independently among plots at any given site, and some populations may be increasing while others are decreasing. These variations reflected microsite differences, such as: soil moisture, herbivory, or mycorrhizae, although populations of moonworts are known to fluctuate widely 

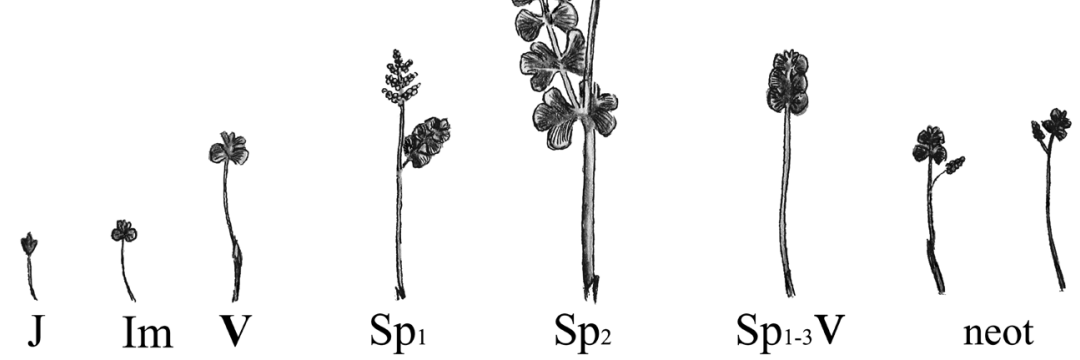

Fig. 4. Scheme of Botrychium lunaria ontogenesis (according to Parnikoza et al. 2008)

Explanations: J - juveniles, Im - immatures, $\mathrm{V}$ - virginile, $\mathrm{Sp}$ - mature reproductive stage have sporophore - generative part of leaf, $\mathrm{Sp}_{1}, \mathrm{Sp}_{2}, \mathrm{Sp}_{1-3} \mathrm{~V}(\mathrm{see}$ page 34), neot - neoteny (see page 34)

without any apparent cause. Populations of aboveground sporophytes fluctuate widely from year-to-year. An individual plant may not appear aboveground every year, complicating attempts to adequately inventory populations (Muller 1993; Johnson-Groh 1998 Chadde \& Kudray 2001). There are some reports about relatively big populations of this species from Western part of Ukraine (Onyshchenko \& Andrienko 2012b). Only one population, consisting of 89 plants, was described (Chubata \& Boyko 2003). In Poland, at the foothills of Dziewicza Góra (143 m a.s.1.), $10 \mathrm{~km}$ northeast of the city of Poznan, one of the largest known populations of this endangered fern was recorded (Olejnik \& Celka 2015). In the Łódź Voivodeship, only a small number of individuals was observed (Woziwoda \& Witosławski 2012).

In case of B. matricariifolium, only mature reproductive stages of ontogenesis (Sp) were described (Krinitsyn 2004). However, in the Wielkopolska populations, some individuals without the sporophore were registered (Celka \& Kasprowicz 2002; Gierczyk et al. 2007). Ukrainian authors indicate small numbers of individuals in populations throughout the species entire range, according to both present and old data. Thus, in the population of Zakarpattia lowland and the one we found in the Middle Dnieper region, there were only 5 and 4 speciemens, respectively, There is also information available on the growth of several individuals in locality near Nizhnya Yarovitsa tract (Chernivtsi Oblast). Population near the Kaniv Zapovednik had no sporophytes since 2007 (Onyshchenko \& Andrienko 2012a). Recently, a big population was found on the Antalovetska Polyana Mt. in Zakarpatiia Oblast. In 2012, this population covered an area of about $14,000 \mathrm{~m}^{2}$. The number of individuals noted in 3 study plots $\left(25 \mathrm{~m}^{2}\right.$ each), reached 43, 30 and 82 (average density $2 / \mathrm{m}^{2}$ ). Probably, this population is a part of a bigger meta-popu- lation (Votkalchuk et al. 2014). A large population size in this locality was also confirmed in 2016 by V. Loya. Situation in Ukraine is similar to situation in Belarus, where populations seldom reach up to a hundred plants (Blazhevych \& Dzhus 2005). In Poland, there were found both single sporophytes and larger populations. The number of sporophytes can reach more than a hundred (Szczęśniak 1998, 2002; Czarna 2002; Gierczyk et al. 2007; Bobrowicz et al. 2004), while population density sometimes reaches 16-20 plants per $\mathrm{m}^{2}$. In Czech Republic, there are populations with single plants and larger - with approx. 50, as well as 100-300 sporophytes (Braun 1999). In Russia, several big populations of this species were also registered (Krinitsyn 2004). The cases of disappearing of well-known populations without any evidence of habitat degradation or other changes, as well as random cases of their regeneration in the previously known sites were described (Braun 1999; Bobrowicz et al. 2004). In Czech Republic, there are also some stable populations that produce annualy more than 100 individuals.

B. multifidum has the following onthogenesis stages: J, Im, V, Sp, Sp ${ }_{1-3}$ V, (Fig. 5). J (the first premature stage) has three to four-separate leaf up to $1 \mathrm{~cm}$ in length. Sometimes, this stage is recognized for the Botrychium species as $\mathrm{J}_{2}$, while initial underground sporophytes without green leaf are recognized as $J_{1}$ (Krinitsyn 2004). Im (the second premature stage) has one-dissected leaf, $2-5 \mathrm{~cm}$ in length. $\mathrm{V}$ (third premature stage) has a larger two-dissected leaf whose length varies up to $10 \mathrm{~cm}$. $\mathrm{Sp}$ (mature reproductive) individuals have the sporophore, while $\mathrm{Sp}_{1-3} \mathrm{~V}$ (Sp mature stage without the sporophore in a given year) has the twice-three-dissected trophophores, and no sporophore that is reduced to a small fragment on the surface of the stalk. The length of trophophilus part in individuals of these stages varies greatly and generally is not a diagnostic feature 


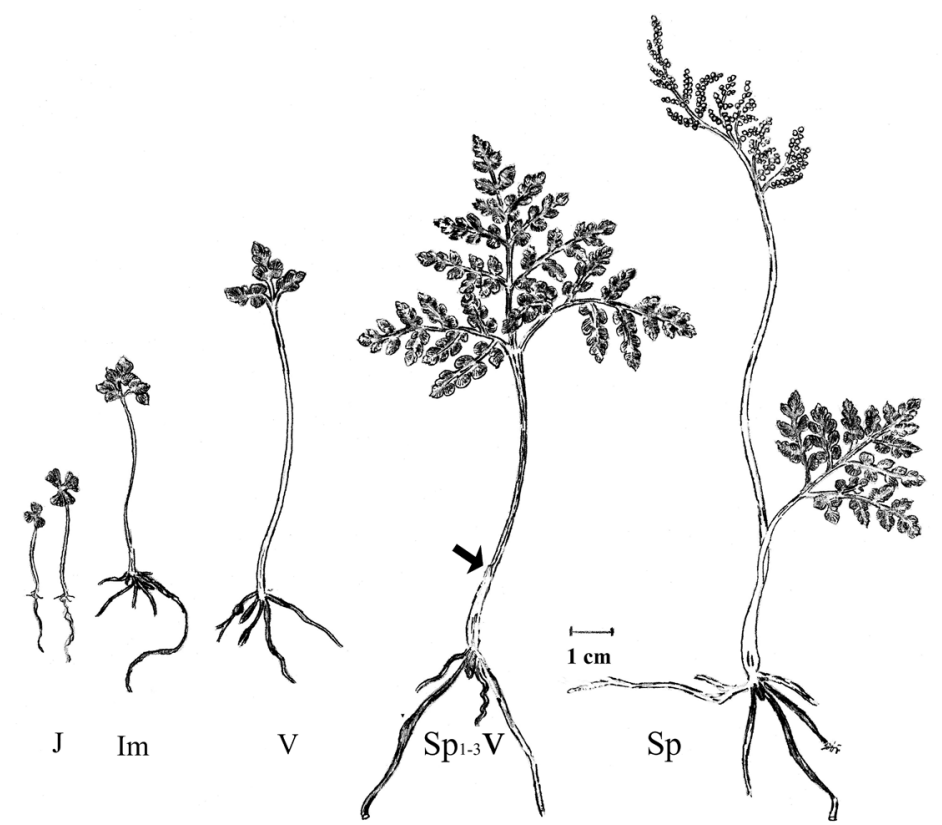

Fig. 5. Scheme of Botrychium multifidum ontogenesis (according to Parnikoza et al. 2008)

Explanations: see Fig. 4 and page 35

(Parnikoza et al. 2008). The data on population structure in Ukraine are very poor. For the described populations, the number of sporophytes varies from single to more than 400. In 2000, a large population with more than 400 plants was found on the Trukhaniv Island (Kyiv city), but recently, it dramatically decreased. According to Anderson (2005), this species cannot stay dormant for a period longer than a few seasons. On the Trukhaniv Island, up to modern times, there has been only one population locus located along a forest roadside (see Parnikoza \& Shevchenko 2009). Quite numerous are also the sites recently described by V. I. Melnik. One of them is the population in the section 60 of the Boyarske forestry of the Boyarska Forest Research Station, Kyiv Oblast (approx. 100 sporophytes per 150 ha) with the density of 7-25 plants per $\mathrm{m}^{2}$ (Melnik 2009). Another population in the Brovarsky forest near the Kyiv electric power station No. 6 had 25 plants in 2005/06 (Melnik 2009). A population in the Desnyansko-Starogutsky National Park (Sumy Oblast) numbered 67 sporophytes (Panchenko 2005). Populations in the secondary postforest meadows of the forest belt of Gorgany, consisted of about 11-50 plants (Klimuk et al. 2006). Eleven sporophytes were described in Vertievka, Chernigiv Oblast (Lukash 1997). In 2004, in the Borovski region of Kharkiv Oblast, 12 plants of different age were found (Melnik 2009). Small populations or even single plants were found in the piedmont to subalpine belts (Chopyk et al. 1977; Malynovsky et al. 2002; Onyshchenko \& Andrienko 2012b). In the case of the Trukhaniv population, a full age structure with the significant presence of juvenile and immature plants was registered (Parnikoza
\& Cukanova 2005; Parnikoza \& Shevchenko 2009). A handful of pre-reproductive specimens occur in the Svyatoshin forestry, Kyiv. For other populations, only some information about juvenile plants is present. Thus, only 2 single juvenile sporophytes were described form the Shumsky District, Ternopil Oblast (Melnik 2009). Most often researchers described populations divided only into two categories: sporophytes either produce spores or not. The presence of $\mathrm{Sp}_{1-3} \mathrm{~V}$ individuals and significant year-to-year variations in the sporophyte number in the described populations were observed (Parnikoza \& Cukanova 2005; Melnik 2009).

In Belarus and Poland, the populations are generally not numerous, often consisting of several plants (Blazhevych 2005). In Górzno-Lidzbark Landscape Park, 14 plants appeared in 2000 and 7 in 2001 (Załuski $\&$ Paszek 2002). More large populations have been recently described from Polish Bieszczady, consisting of 100-1000 plants (Piękoś-Mirkowa et al. 2008; Szczęśniak et al. 2014). In Polish populations, numbers of sporophytes and $\mathrm{Sp}_{1-3} \mathrm{~V}$ also fluctuated (Celka $\&$ Kasprowicz 2002; Blazhevych 2005). In one of the newly discovered sites, there were about 30 specimens, in another -50 . The majority of plants from population in the Białowieża Forest had developed leaves (Laskowska-Ginszt \& Wołkowycki 2012). Most sites of $B$. multifidum in north-east Poland usually had from only single to several dozen of plants (Wołkowycki \& Pawlikowski 2008).

There are no studies of onthogenesis stages for $B$. simplex. They are likely to be similar to those in B. lunaria. Known populations ranged from a few to ten 


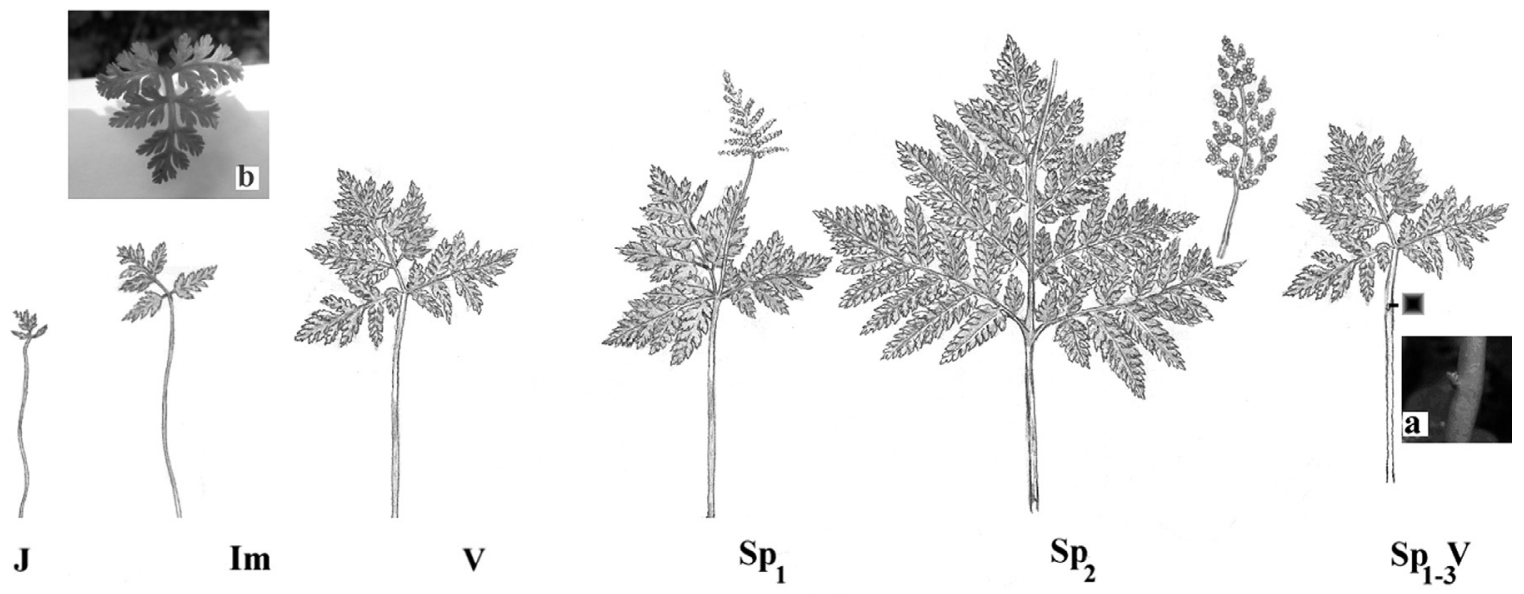

Fig. 6. Scheme of Botrychium virginianum ontogenesis (according to Parnikoza et al. 2014) Explanations: see Fig. 4 and page 37

individuals (Żukowski et al. 2014). A population that was found in 2006 in the Minsk region by M. Dzhus (pers. comm.) numbered about 30 plants per square meter.

For B. virginianum, the following onthogenesis stages were determined: $\mathrm{J}$-juvenile (the first premature stage) with the minimally dissected trophophore, Im immature (the second premature stage) with the small, bi-dissected trophophore, the ends of the segments are blunt or rounded, $\mathrm{V}$ - virginile (the third premature stage) individuals have the bi-three-dissected tropophore, the ends of the segments are sharp. The matture sprophytes (Sp) can be divided to young ones $\left(\mathrm{Sp}_{1}\right)-$ with the small sphorophore part, and mature ones $\left(\mathrm{Sp}_{2}\right)$ with the biggersporophore part. Mature sporophytes of reproductive age without the sporophore (only a small, reduced fragment on a leaf stem) $-\mathrm{Sp}_{1-3} \mathrm{~V}$ (Fig. 6), are also quite often observed in populations; for the more detailed description see (Parnikoza \& Krinitsyn 2014; Sirotina et al. 2014). $\mathrm{Sp}_{1-3}$ V stage is easy to identify due to the absence of the developed sporophore (Fig. 6).

$B$. virginianum in old records was indicated as a species that grows in groups of single individuals. In one of the two current Ukrainian localities, $3 \mathrm{Sp}$ and $6 \mathrm{Sp}_{1-3}$ V were observed in 2006 (Melnik 2009). Similar situation - a group of single individuals, was observed in this place over the next years of investigations (O. Rak, pers. comm.). In Belarus, it was also found as single plants and small groups on the plots of several $\mathrm{m}^{2}$ (Blazhevych \& Dubovik 2005). A similar distribution pattern of this species was noted in the Tver Oblast of Russia (Notov 2002b). The Polish single population (Pawlikowski 2011), was divided into two subpopulations: the first one, in 2010, consisted of 14 plants ( $5 \mathrm{~J}$ and $1 \mathrm{Sp}$ ), while in 2012, a similar number of individuals was observed, 2 of them were J. The second subpopulation, found in 2012, had about 55 plants (9 sporulating) (Pawlikowski 2011). In Northern Russia, populations have more plants, like a population in the Kologrivski Forest Nature Reserve (Manturov District, Kostroma Oblast),where there are about 1000 plants with an average density of 136 individuals $/ 100 \mathrm{~m}^{2}$ (Parnikoza \& Krinitsyn 2014). $\mathrm{Sp}_{2}$ and $\mathrm{Sp}_{1-3} \mathrm{~V}$ dominate in this population. Populations with a high number of individuals were also reported from Sweden (Ståhl 1998). Localities with number from 1 to approximately 20 plants, were described by us from Lehigh Valley in Pennsylvania. These individuals were represented mainly by mature sporophytes, mostly not sporulating $\left(\mathrm{Sp}_{1-3} \mathrm{~V}\right)$ (Parnikoza \& Krinitsyn 2014).

$O$. vulgatum is represented by populations that consist of a large number of sporophytes that may have the sporophore or not. Indiviudal sporophytes, according to Filin (1995) and our observations in the Cherkasy Oblast populations can be interconnected by horizontal rhizomes, forming compact clusters of clones.

\subsection{Main threats}

The causes for the withdrawal of species from Ophioglossaceae should be sought, on the one hand, in their relict biology and, on the other hand, in rapidly changing habitat conditions. Less numerous populations of the ferns of adder's-tongue family may be also exposed to random factors that can destroy the entire population. The main natural threat described in literature for all Ukrainan species of Ophioglossaceae is natural succesion. The species is a poor competitor and its habitats are typically small patches (tens to hundreds of square feet in area), where some soil disturbance has occurred or where other factors prevent the occurrence of dense turf or thick litter layers. This species is easily outcompeted when the plant cover becomes dense (Gilman 2003; Chadde \& Kudray 2001). It was noted that Ophioglossaceae are species that 
apparently employ a k-strategy, colonizing available but potentially short-term habitats. The dispersal units are light, wind-blown spores, presumably capable of great vagility. Establishment and persistence of populations depends on the availability of colonizable habitat patches, contact with the fungal associate, and the maintenance of open habitat by disturbance over time as most species are poor competitors, but good long-distance dispersers (Muller 1999; Gilman 2003). $B$. lunaria in US East Coast probably was lost from many lowland sites before 1930, and this loss continued, particularly in N. England, due to grassland overgrow and shrub invasion (Gilman 2003). However in Ukraine and Poland, the species is often observed in forests, especially on floodplains and in pine forests. Additionally, in case of all previously cited references, the detailed annual monitoring results are absent. In such situation, all conclusions about succession impact and active conservation regime in case of Ophioglossaceae should be tentative. Meanwhile, some authors directly stated that efficient methods of protection of this species are not known (Bobrowicz et al. 2004). In the opinion of American researchers, without active protection of these plants, which requires clear guidelines - and courage to follow these guidelines, because this may involve some disruptive activities, such as intensive soil disturbance - active management may not be beneficial. Any studies should be well justified and non-intrusive (Gilman 2003).

Another danger comes from herbivorous animals, such as hoofed mammals or molluscs (Nowak \& Nowak 2008; Celka \& Kasprowicz 2002; Szczęśniak \& Tlałka 2014). In Kyiv conditions, the trophophores of $O$. vulgatum are sometimes readily eaten. According to our observations, dry seasons can limit the number of developed sporophytes.

Human impact, such as afforestation of dry grasslands and establishing pine monocultures accompanied by ploughing of herb layer in clearings, can also pose a threat (Kujawa et al. 2005). The worst threat currently appears to be the sharp decline in potentially suitable territories (including those already reserved for nature conservation). For example, the population of B. multifidum on the Trukhaniv Island can be totally destroyed by barbarous property development. The biotops of $O$. vulgatum in Ukraine are very often used for private buldings, which poses strong danger for this species and makes its protection necessary. In Poland, O. vulgatum localities are often destroyed for farming purposes (Ceynowa-Giełdon 1999). A change in water regime can also be fatal (e.g., after melioration) as part of the overall regression of the habitat (Notov 2002a, 2002b). Destruction of potential habitats was a factor contributing to the $B$. virginianum range reduction. One population from Poland was completly destroyed due to logging and the following afforestation (Pawlikowski 2014). The destructive influence of tree-cutting was also noted in Belarus and Ukraine (Blazhevych \& Dubovik 2005; Votkalchuk et al. 2014). Identified threats to B. lunaria include drought, fire, timber harvesting, collecting, herbicide application, herbivory, exotic earthworms, and forest succession (USDA Forest Service 2000). Regionally, overgrazing can also be a factor (Maslova et al. 2003). In relation to burning and hay-making, there are no data for Ukraine, but these activities also may be dangerous for sensitive plants (Boreiko et al. 2017).

\subsection{Current protection status and a proposal of its correction}

According to the Red Data Book of Ukraine, B. lunaria is (Andrienko 2009) a vulnerable (category vulnerable according to IUCN) species. This species is also protected in Dnipropetrovsk Oblast (Andrienko \& Peregrym 2012). B. lunaria is protected in following zapovedniks: Carpathians Biosphere, Kanivsky, Crimean, Yaltinsky Mountain-Forest, Roztochchya, and Gorgany and in the following National Parks (NP): Karpatsky, Shatsky, Yavorivsky, Vyzhnytsky, Synevir, Huculszhyna, Skolivski Beskydy, North Podillya, Homilshanski Lisy, Verhovinsky, Podilske Towtry; in national zakazniks (special reserves): Hapkalsky (Crimea), Lunkivsky and Chorny Dil (Chernivtsi Oblast), local zakazniks: Vasylkivsky Carpaty (Kyiv Oblast), regional forest zakaznik - Volodymyrivska dacha (Kharkiv Oblast), and the National Nature Monument Parasotsky Forest in Poltava Oblast (Klokov 1924; Andrienko 1996; Chopyk et al. 1988; Popovych 2002; Klimov et al. 2005; Kuzminska 2006; Rudenko 2007). In the reported sites of the Shatsky NP, the species has not been observed for 20 years (Yaschenko 2007).

It is necessary to create new or extent some existing conservation areas, namely: to establish a new national park - Dniprovsky NP (including the surroundings of Mochnachy villages) - in the Ripkinsky District, Chernihiv Oblast, to incorporate the woodland tract Feofania into the Holosiyivsky NP in Kyiv and the Kosmach village sorundings (Kosivsky District) into the strictly protected area of Huculszhyna NP. The enlargment of Verkhovynsky NP (including modern Ophioglossaceae localities) is also recommended.

Aditionally a system of botanical zakazniks (special reserves) should to be created: near Repuzincy village (Zastanivsky District) in Chernivtsi Oblast, Verchnia Rozanka village, Chorna Ripa Mt., and Volosianka village (Skolivsky District) (it is also possible to include it in the Skolivske Beskidy NP), near Svirz castle (Peremyszlansky District) in Lviv Oblast, near the old cemetery in Kremenets in Ternopil Oblast, in Bohunia 
forestry (Zhytomyrski District) in Poterebchukovy Riv tract near Stary Velidnyky village (Ovrucki District), Zhytomyr Oblast, in Nowozanowo tract in Kharkiv city, on Arpataska jaila near Zelenogirya village (Sudak region), Crimea.

B. matricariifolium is also listed as on the brink of extinction (similar to critically endangered according to IUCN) in the Red Data Book of Ukraine (Danylyk et al. 2009), as well as in Appendix I to the Bern Convention, and is also protected in Zakarpatiia \& IvanoFrankivsk Oblasts (Bern Convention 1979; Parnikoza et al. 2008; Andrienko \& Peregrym 2012). It has status Near Threatened (NT) according to the last European Red List (Bilz et al. 2011).

The protection of B. matricariifolium in situ is realized in such SPAs as: Carpathians Biosphere Zapovednik and, probably, North Podillya NP. It is necessary to include the dam leading to Zmiyini Islands into the Kanivsky Nature Zapovednik, and enlarge the Verkhovynsky NP (including mountain valley Preluchka). On the Tisza Lowland - Otrosh Tract near Mukacheve, (Mukachevsky District), Antalovecka polyana Mt. (Uzhorodsky District), Makovica Mt., near Turii-Remety village (Perechynsky District), Sitkovo village near Kvasy (Rakhivsky District), Zakarpatiia Oblast and near Nizhnya Yarovitsa tract (Putilsky District), Chernivtsi Oblast, $25 \mathrm{~km}$ on SW from Kovel (Kovelsky District), Volyn Oblast, zakazniks must be established.

Active protection of B. matricariifolium by periodical cutting of shrubs and young trees was proposed (Votkalchuk et al. 2014), but as we mentioned, there are no real data about effects of such interventions. There was a report about cultivation of this species in one of the Ukrainian dendrological parks (Votkalchuk et al. 2014).

B. multifidum is listed as a rare species according to the Red Data Book of Ukraine (Sichak et al. 2009) (i.e., vulnerable according to IUCN) and is protected according to Appendix I to the Bern Convention. It has a status of Data Deficient (DD) according to the last European Red List (Bilz et al. 2011). It is also included in the Regional Red Lists of Zakarpatiia, Chernivtsi, Ivano-Frankivsk, Chernihiv oblasts and Kyiv city (Andrienko \& Peregrym 2012). The protection of $B$. multifidum in situ is realized in such SPAs as: Carpathian Biosphere, Mykhailvska tselyna, Gorgany, zapovedniks, the NPS: Carpatsky, Desnyansko-Starogutsky, Verkhovinsky, Hetmansky, Cheremosky, Shatsky and Holosyyvsky, and the Dermansko-Mostivsky Regional Lanscape Park (KW; Volodymyrets 2005; Klimuk et al. 2006; Onyshchenko \& Andrienko 2012a, 2012b; Bezsmertna \& Heluta 2013).

It is also need to establish new SPAs and enlrge some existiong. It is necessary to create NPs: Dniprovsky Ostrovy in Kyiv, Dniprovsky in Chernigiv
Oblast, to enlarge Holosyyvsky (Kyiv) and Cheremosky (Chernivtsi Oblast) NPs and create some zakazniks in the sites of large populations in Kyiv on the Trukhaniv and Dolobecky Islands, near Almazne lake in Darnitske forestry, Kyiv city, the Chortoryiske woodland tract near Shevchenkove village (Gluhivsky District), and section 57 of Druzbivka forestry near Bilitsia village (Yampolsky District) in Sumy Oblast should be included in Verkhnyoesmansky zakaznik. Zakazniks should be created near Losinec village (Turkivsky District), Lviv Oblast, Volyn` department of Kremenez forestry, (Shumsky District), Ternopil Oblast, near Shedrogor village (Ratnivsky District) and on former proving ground near Volodymyr-Volynsky, Volhyn Oblast, near Vertiivka village (Nizhinsky District), and near Uglova Rudnia village (Ripkinsky District), Chernihiv Oblast, near a former recreation camp Morsky, north of Lutiz village (Vyshgorod District), sect 60 of Boyarka forestry (Kyivo-Sviatoshynsky District), Kyiv Oblast in the vicinities of Gorokhovatka village (Borivsky District), Kharkiv Oblast.

There is some experience in the cultivation of a close relative of B. multifidum - Botrychium robustum (Rupr.) Underw. (Stetsenko 2000), thus, an artificial creation of new populations both in situ and in botanical gardens might be possible.

B. simplex should be included in the Red Data Book of Ukraine as an extinct species. It is also nessesary to look for modern populations of this species and establish protected ares for it. Thus, in Belarus, this species that was considered as extinct in this country, but it was found again in 2006 (M. Dzhus, pers. comm. 2014). As one of the rarest species in Europe, it is protected according to Bern Convention. It was included in third edition of the Polish Red Data Book with category EX (Żukowski et al. 2014).

B. virginianum is protected by the Red Data Book of Ukraine as a species on the brink of extinction (analogous to critically endangered (CR) according to IUCN) (Kagalo \& Chorney 2009). It is also included in the Regional Red Lists of Lviv, Chernivtsi and Khmelnytskyi Oblasts and Kyiv city (Andrienko \& Peregrym 2012). Because there are only two confirmed populations, the species should be additionally protected. As the first step, zakazniks need to be created in the vicinities of Uglova Rudnia and Zubachy villages (Ripkynsky District), Chernigiv Oblast. As the second step, it need to be included in the strict protection zone (Ia category of IUCN) of the projected Dniprovsky National Park. The North Podillya National Park should be enlarged to include old registered sites of $B$. virginianum.

According to literature (Blazhevych \& Dubovik 2005) and our own observations, B. virginianum, like other species, practically, cannot be transplanted 
- without symbiotic fungi, it has no chance to form spores; which makes searching for the potential sporeintroduction habitats another priority.

$O$. vulgatum is officially protected in Kyiv city, Kyiv, Zakarpatiia, Ivano-Frankivsk, Lviv, Rivne, Chernivtsi, Chernihiv, Sumy, Zhytomyr, Vinnitsa, Poltava, Odessa, Dnipropetrovsk, Kherson, Luhansk, and Kharkiv Oblasts (Andrienko \& Peregrym 2012). In Chernivtsi Oblast, its status was determined as Critically Endangered (Tokariuk 2005). The species is also protected in SPAs: Carpathians and Chornomorsky Biosphere Zapovedniks, Crimean Yalta Mountain Nature, Dniprovsko-Orilsky zapovedniks, and Mykhaylivska Tselina zapovednik. It is also protected in the following NPs: Uzansky, Prip 'at-Stochyd Shatsky, Hetmansky, Ichnyansky, Desniansko-Starogutsky, Mezinsky, Oleshkivsky Pisky, Boloberezia Sviatoslava, Viznicky, regional landscape parks: Nyzhnyovorsklyansky, Mizhrychensky and Kremenchutski plavni; national zakazniks Holytsky (Ternopil Oblast), Urochische Kormin (Volyn O.), Lunkivsky, Chorny Dil (Chernivtsi O.), Kamoretsky, Zamglaj (Chernihiv O.), Au-Dag, Great Canyon of Crimea, Kubalach, Baidarsky (AR Crimea) and regional zakazniks: Bobrovnya, Zhukiv Island, Kozachy-Olzhyn Islands (Kyiv city), Kovalivsky Yar (Kyiv O.), and in the Regional Natural Monument Zhalutynska (Kharkiv city) (KW; Tkachenko et al. 1998; Chorney et al. 2001; Kucherevski 2001; Popovych 2002; Andrienko et al. 2007; Nakonechny 2007; Vakhrusheva 2015; Parnikoza unpubl. data 2015).

In the same time, the creation of new special protected areas is required for this species. It is necessary to include the dam leading to Zmiyini Islands and the mouth of the River Ros into the Kanivsky Nature Zapovednik, create new national parks: Dniprovsky Ostrovy in Kyiv, Dniprovsky (including Uglova Rudnia village surroundings), Podesinia (with flood plane near Zukin, Voropaiv and betwen Zazymia and Puhivka villages) and Mizhrychensky (out of the current RLP) in Kyiv and Chernigiv Oblast, Siversko-Donetsky (including souroundings of Malynovy village) in Luhansk Oblast, Samarsky Bir in Dnipropetrovsk Oblast, to enlarge the Oleshkivski pisky NP by including in it Burkutske plavni tract and new zakazniks (special reserves): Tkhorynsky near Begun village (Ovrucky District) and near Barashyvka village (Zhytomyrsky District) Zhytomyr Oblast, Stavkovy yar in Vyshgorod, Lubyanka (Borodiansky District) and Maly Bukrin villages (Myronivsky District), Kyiv Oblast, Svyatoshynsky stavy on Nivka river, Gorbachycha and Vysoky luh on Dnieper's left bank floodplain and Pokal on Dnieper's right bank floodplain in Kyiv city, near Glybochok and between Spaska and Revne villages', on north-easten slope of mountain meadow Zanoza (Storozynecky District), near villages Kulykivka, Ternavka (Gercaivsky District) and outskirts of Boyany village in Hukiv ravine (Novoselytsky District), near Valya Kuzmina village (Glybosky District), on Tsetsino hill in Chernivtsy city, Chernivtsi Oblast, near village Selets on Rata floodplane (Sokalsky District), on swamp near Kniazy Mist village (Mostysky District), near Brody, near Boratyn village (Brody District), Lviv Oblast near Klochava village in Mizgyrsky District, Zakarpatiia Oblast, in the vicinities of Mala Andruga village (Kremenetsky District), Ternopil Oblast, near Turja Polana village, on mountain meadow Rivna (Perechynsky District), on Antalovecka polana mt. slope near Nevicke (Uzgorodsky District), Zakarpatiia Oblast, near Zatyshia village (Shatsky District), in vicinities of Choteshyv village (Kamin-Kashyrsky District), Volyn Oblast, in vicinities of Sribne village (Radyvilivsky District), Rivne Oblast, in section 58 of Druzbivka forestry near Bilitsia village (Yampilsky District), Sumy Oblast, on old fruit garden near Skyt ki village (Ripkinsky District), near Ivanyne village (Semenivsky District), Chernigiv Oblast, on Nowozhanovo tract in Kharkiv city, in the Diyvka Dnieper floodplain forest and Sugakivski forest near Kirovske in Dnipro city, on Pylipcewi ozera tract (Oleshkivsky District), Kherson Oblast, near Ruske village (Bilogorsky District) in Crimea.

Due to the lack of Red Data Book protection status, $O$. vulgatum is not included in the research programs of rare species monitoring, because there are no wide studies of this species in Ukraine. There is some experience with $O$. vulgatum cultivation (Stetsenko 2000), so the artificial creation of new populations both in situ and in botanical gardens is possible. It is also necessary to test whether some Ukrainian specimens belong to $O$. azoricum and in case of confirmation, to take this species into account.

\section{Final remarks}

All species of the family Ophioglossaceae are rare in Ukraine. Compared to the the records of the $19^{\text {th }}$ to the beginning of the $20^{\text {th }}$ centuries, there is a decline in the number of every Ophioglossaceae species populations. Most critical is a present situation with $B$. simplex - no extant populations were found. $B$. virginianum and $B$. matricariifolium are currently known for certain only from 2 and 7 sites, respectively. Botryhium multifidum, $B$. lunaria and O. vulgatum demonstrate decreasing number of records since 1980, in comparison with previous period, especially, in the lowland part of the country. This tendency is accompanied by a very low stability of well known populations - only some of them have been existing for the period before 1980 to modern times. This, in general, corresponds to the situation in Poland and other European countries. 
Review of habitat preferences showed that it is difficult to determine specific vegetation communities critically important for Ophioglossaceae, on the contrary, they need the complex of different communities. Most of the currently existing populations (at least those for which there are some data) have few plants, thus, all species need more efficient protection.

$B$. simplex and $O$. vulgatum should be included in the Red Data Book of Ukraine. It would allow to preserve them (B. simplex in case of new findings) either by preserving the land or by using the only working legal alternative designed specifically for plant conservation (Parnikoza et al. 2008; Law of Ukraine 2017). It is not enough to only protect the sites on the already preserved lands; at least six more National Parks should be created, as well as a lot of new zakazniks; some existing SPAs should be enlarged. This will be a specific measure to implement the Bern Convention requirements for the Ukrainian Ophioglossaceae species. In all SPAs with Ophioglossaceae populations all forms of tree logging as the most dangerous human activity for all Ophioglossaceae must be prohibited. To work out what measures need to be taken to preserve newly discovered populations, it is necessary to annually monitor the quantity, age structure (based on the developed methodology), spore production and seedling recruitment in the network of experimental plots, as well as to monitor
Ophioglossaceae population stability during the process of succession.

Considering the lack of data about the influence of different factors on Ophioglossaceae, all regulation measures (of active conservation approach) should be used carefully only after experimental testing. In case of communities protection besides Molinion caeruleae wet mesotrophic meadows, code 6410 (protected according to the European habitat directive http://ec.europa.eu/ environment/nature/legislation/habitatsdirective/index_en.htm), we propose to protect the areas potentially suitable for Ophioglossaceae, in which occur ecologically related species of Orchidaceae, Pyrolaceae or other groups of mycorrhizal plants.

Updated scientific archive of Ukrainian Ophioglossaceae fundings accessible on http://www.myslenedrevo. com.ua/uk/Sci/Nature/archive-ophioglossaceae-ukraine.html

Acknowledgments. This investigation was conducted as part of collaboration between the Faculty of Biology, Adam Mickiewicz University in Poznań and Institute of Molecular Biology and Genetics NAS of Ukraine. We also thank I. Chorney, V. Melnik, V. Loya, O. Rak, S. Panchenko, R. Cherepanyn, D. Inozemtseva, Yu. Krasilenko, N. Saidachmetova, O. Bezsmertna, O. Zygalenko, V. Geluta, Yu. Bengus, I. Kvakovska, L. Boruskevich, P. Buzunko, M. Bogomaz and all the people who gave us information about populations and provided the photos of Ophioglossaceae species in Ukraine.

\section{References}

Anderson D. G. 2005. Botrychium multifidum (Gmel.) Rupr. (leathery grapefern): a technical conservation assessment. 73 pp. USDA Forest Service, Rocky Mountain Region. Available: www.fs.fed.us/r2/projects/scp/ assessments/botrychiummultifidum.pdf

Andrienko T. L. 1996. Botrychium lunaria (L.) Sw. In: YU. R. SHElaG-Sosonko (ed.). Red Data Book of Ukraine, p. 23. Ukrainian encyclopedia im M. P. Bagana, Kyiv (in Ukrainian).

Andrienko T. L. 2009. Botrychium lunaria (L.) Sw. In: YA. P. DiDUkH (ed.). Red Data Book of Ukraine. Vegetable kingdom, p. 34. Globalkonsalting, Kyiv (in Ukrainian).

Andrienko T. L., Lukash O. V., Pryadko Yu. I., Karpenko Yu. O., Loban` L. O., ZhygalenKo O. A., Arap R. Ya. \& DIDYK O. V. 2007. Rare species of vascular plants of the Chernihivska region and their representation in the Nature Conservation Lands of the region. Zapovidna sprava w Ukraini 13: 33-37 (in Ukrainian).

Andrienko T. L. \& Peregrym M. M. (ed.). 2012. Official lists of regional rare plants of administrative territories of Ukraine (reference book). 148 pp. Alterpress, Kyiv (in Ukrainian).

Austrheim G. \& Olsson G. 1999. How does continuity in grassland management after ploughing affect plant community patterns? Plant Ecol 145: 59-74. doi: 10.1023/A:1009804509239

BARBARYCH A I 1955. Flora and vegetation of the Polissiya of Ukraine - descriptions about nature and agriculture of Ukrainian Polissiya. 269-321 pp. Published by Kyiv University, Kyiv (in Russian).

Belgard O. L. 1938. Ravine forests alongside the Samara River. Collection of the scientific works of biology department of Dnipropetrovsk State University 2: 107-130 (in Ukrainian).

Bern Convention 1979. The Bern Convention on the Conservation of European Wildlife and Natural Habitats. http:/www.coe.int/en/web/conventions/full-list/-/ conventions/treaty/104

Besser W. 1822. Enumeratio plantarum hucusque in Volhynia, Podolia, Gub. Kiioviensi, Bessarbia CisTyraica et circa Odessam collectarum, simul cum observationibus in primitias florae Galiciae Austriacae. 111 pp. Typis Josephi Zawadzki Universitatis Typographi.

Bezsmertna O. O. \& Heluta V. P. 2013. Distribution of Botrychium multifidum (Ophioglossaceae) in Ukraine. Ukr. Bot. J. 70(6): 792-795 (in Ukrainian).

Bezusko L. G., Mosyakin S. L. \& Bezusko A. G. 2011. Patterns and trends of development of the plant cover 
of Ukraine in the Late Pleistocene and Holocene. 448 pp. Alterpress, Kyiv (in Ukrainian).

Bilz M., Kell S. P., Maxted N. \& Lansdown R. V. 2011. European Red List of Vascular Plants. 142 pp. Luxembourg, Publications Office of the European Union.

Blazhevych R. Yu. 2005. Botrychium multifidum (S. G. Gmel.) Rupr. In: G. P. Paszkov, L. V. Kaleda, V. N. Logvin \& Petrikov A. M. (eds.). Red Data Boook of Belarus. Plants, pp. 37-38. Belaruskaya Encyklapedyya imya P. Brouvki, Minsk (in Russian).

Blazhevych R. Yu. \& Dubovik D. V. 2005. Botrychium virginianum (L.) Sw. In: G. P. Paszkov, L. V. KaledA, V. N. Logvin \& Petrikov A. M. (eds.). Red Data Boook of Belarus. Plants, pp. 35-36. Belaruskaya Encyklapedyya imya P. Brouvki, Minsk (in Russian).

Blazhevych R. Yu. \& Dzhus M. A. 2005. Botrychium matricariifolium (A. Br. ex Döll) Koch. In: G. P. PAszkov, L. V. Kaleda, V. N. Logvin \& Petrikov A. M. (eds.). Red Data Boook of Belarus. Plants, pp. 38-39. Belaruskaya Encyklapedyya imya P. Brouvki, Minsk (in Russian).

Bobrowicz G., Narkiewicz C. \& Szczęśniak E. 2004. Occurence of Botrychium matricariifolium (Retz) A. Braun ex W.D.J. Koch (Ophioglossaceae) in lower Silesia Acta Botanica Silesiaca 1: 161-166.

Boreiko V. E., Brynikh V. A. \& Parnikoza I. Yu. 2017. Criticism of haymaking and other regulatory measures in steppe and other strictly protected areas (category I-a IUCN). Kyiv ecological and cultural center. 136 pp. Logos, Kyiv (in Ukraininian). http:// ecoethics.ru/wp-content/uploads/2017/12/Kritikasenokosheniya.pdf

BortnYAK M. M. 1962. To the distributions of some new and less known plants of Kyiv Polissiya. Ukr. Bot. J. 19(3): 79-84 (in Ukrainian).

Braun A. 1999. Botrychium matricariifolium In: J. ČEřOvSKÝ \& Š. MaglockÝ (eds.). Červená kniha ohrozených a vzácných druhov rastlín a živočíchov SR a ČR. Vyššie rastliny, 5, p. 58. Praha a.s. Bratislava.

Celka Z. \& Kasprowicz M. 2002. Nowe stanowiska Botrychium matricariifolium i B. multifidum (Ophioglossaceae) w Wielkopolsce. Fragm. Flor. Geobot. Ser. Polonica 9: 75-79.

Ceynowa-GieŁdon M. 1999. Ophioglossuum azoricum (Pteridiophyta, Ophiogolssaceae) z polskiego wybrzeża Bałtyku. Fragm. Flor. Geobot. Ser. Polonica 6: 171-177.

Ceynowa-GieŁdon M. 2001. EX Ophioglossuum azoricum C. Presl. Nasięźrzał wielolistny. In: R. KAźMIERCZAKOwA \& K. ZARZYCKI (eds.). Polish Red Data Book of Plants. Pteridophytes and flowering plants, wyd. II, pp. 3839. PAN, Instytut Botaniki im. W. Szafera, Instytut Ochrony Przyrody, Kraków.

Chadde S. \& Kudray G. 2001. Conservation Assessment for Botrychium lunaria (Common Moonwort). USDA Forest Service, Eastern Region. 38 pp. Requisition no. 43-54A7-0-0036/Project no. Ottawa-00-06.

Chopyk V. I., Bortnyak M. M., Voytyuk Yu. O., PohrebenNyK V. P., Kucheryava L. F., Nechytaylo V. A., LyubCHenko V. M. \& SHevchyк V. L. 1998. A checklist of the vascular flora of Middle Dnipro Region. $139 \mathrm{pp}$. Phytosociocentre, Kyiv (in Ukrainian).
Chopyk V. I., Kotov M. I. \& Protopopova V. V. 1977. Key to plants of the Ukrainian Carpathians. 435 pp. Naukowa Dumka, Kyiv (in Ukrainian).

Chopyk V. I., Scherbak N. N., Ardamatskaya T. B., Gegerin V. P., Korneev A. P., Kryzhanovski V. I., Lysenko V. I., Movchan Yu. V. \& Nekrutenko Yu. P. 1988. Rare and disappearing plants and animals of Ukraine: a handbook. 256 pp. Naukova dumka, Kyiv (in Russian).

Chorney I. I., Budzhak V. V., Tokariuk A. I. \& Nyckyrsa T. D. 2004. Genus Botrychium Sw. (Ophioglossaceae) in the flora of Bukovina - chorological characteristic. Naukowyi Visnyk Chernivetskoho Uniwersytetu: Zbyrnyk Naukowych Prac. 194: 132-137. Chernivtsi (in Ukrainian).

Chorney I. I., Skilsky I. V., Korzhyk V. P. \& Budzhak V. V. 2001. Nature Conservation Lands of Bukovyna of the national (state) significance as the basis for regional environmental network. Zapovidna sprava w Ukraini 2: 73-98 (in Ukrainian).

Chornous O P 2005. Floristical findings in the Shostkinsky geobotanical rayon (region), Sumska region. Ukr. Bot. J. 2: 360-364 (in Ukrainian).

Chrtkowá A. 1997. Botrychium matricariifolium A. Braun - vratička heřmánkolistá - In: S. HejnÝ \& B. SLAviK (eds.). Kvétena České Republiky, 1, 227-228 pp. Academia, Praha.

Chubata T. \& Boyko S. 2003. Rare species of the flora of Kremenetsky Gory - Rol' pryrodno-zapovidnyh terytoriy Zahidnoho Podilliya ta Yury Oytsovskoi u zberezhenni biolohichnoho ta landshaftnoho riznomanittya. Collection of scientific manuscripts. Hrymayliv, Ternopil : 415-419 (in Ukrainian).

Council Directive 1992. Council Directive 92/43/EEC of 21 May 1992 on the conservation of natural habitats and of wild fauna and flora. Official Journal of the European Communities. No L 206: 7-50.

Czarna A. 2002. Występowanie Botrychium matricariifolium (Retz.) A. Braun ex W. D. J. Koch w Lesie Taczanowskim koło Pleszewa (Wielkopolska). Rocz. AR Pozn. 347, Bot. 5: 27-29.

Danylyk I. M., Kish P. Ya., Melnik V. I. \& Sichak N. M. 2009. Botrychium matricariifolium (A. Braun ex Döll) W. D. J. Koch. In: Ya. P. Didukh (ed.). Red Data Book of Ukraine. Vegetable kingdom, p. 35. Globalkonsalting, Kyiv (in Ukrainian).

Didukh YA. P. (ed.). 2000. Ecoflora of Ukraine, 1, 284 pp. Phytosociocentre, Kyiv (in Ukrainian).

Didukh YA. P. (ed.). 2009. Red Data Book of Ukraine. Vegetable kingdom. 912 pp. Globalconsalting, Kyiv (in Ukrainian).

DidukH Ya. P. 2011. The ecological scales for the species of Ukrainian flora and their use in synphytoindication. Phytosociocentre, Kyiv (in Ukrainian).

Didukh Ya. P. \& Protopopova V. V. 2000a. Botrychium multifidum (S. G. Gmel.) Rupr. In: Ya. P. DidukH (ed.). Ecoflora of Ukraine, 1, 114-115 pp. Phytosociocentre, Kyiv (in Ukrainian).

Didukh Ya. P. \& Protopopova V. V. 2000b. Botrychium lunaria (L.) Sw. In: Ya. P. DidukH (ed.). Ecoflora of Ukraine, 1, 110-111 pp. Phytosociocentre, Kyiv (in Ukrainian). 
Didukh Ya. P. \& Protopopova V. V. 2000c. Botrychium matricariifolium (A. Braun ex Döll) W. D. J. Koch. In: Ya. P. Didukh (ed.). Ecoflora of Ukraine, 1, 112-113 pp. Phytosociocentre, Kyiv (in Ukrainian).

Didukh Ya. P. \& Protopopova V. V. 2000d. Botrychium virginianum (L.) Sw. In: Ya. P. DidUKH (ed.). Ecoflora of Ukraine, 1, 116-117 pp. Phytosociocentre, Kyiv (in Ukrainian).

Didukn Ya. P. \& Protopopova V. V. 2000e. Ophioglossum vulgatum L. In: Ya. P. DidukH (ed.). Ecoflora of Ukraine, 1,107-109 pp. Phytosociocentre, Kyiv (in Ukrainian).

Dmytrash-Vatseba I. I. 2018. Rare Species of South Opilla: State of Populations, Treats, Perspectives of Protection. Qualification Scientific Work. PhD Thesis in Biology. Kyiv (in Ukrainian).

Dostál J. 1984. Familie Ophioglossaceae Rautenfarngewächse. In: H. J. Conert, U. Hamann, W. SchultzeMotel \& G. Wagenitz (eds.). Gustav Hegi Illustrierte Flora von Mitteleuropa, 1, Pteridophyta, 84-98 pp. Verlag Paul parey, Berlin-Hamburg.

Dubovik D. V. \& LebiedKo V. N. 2015. Botrychium simplex E. Hitchc. In: I. M. KachanovskiY, M. Ye. NiKIforov, V. I. Parfenov, O. I. Borodin, A. V. Pugachevskiy, V. M. Baychorov, O. S. Gapiyenko, A. S. Giryachev \& T. P. Yevdaseva (eds.). 2015. Red Data Book of Belarus, Plants: rare and threatened species of wild spread plants, 4. ed., 19-20 pp. Belaruskaya Encyklapedyya imya P. Brouvki, Minsk, (in Russian).

FiliN V. R. 1995. Ophioglossum vulgatum L. In: V. N. PAVLOV \& V. N. Tiкномirov (eds.). Biological flora of Moscow Oblast 11: 4-36 (in Russian).Fodor S. S. 1974. The Flora of Transcarpathia. 208 pp. Vyscha shkola, L'viv (in Ukrainian).

Fomin A. V. 1938. Pteridophyta. In: E. Bordzilowski (ed.). Flora URSS, 1, 37-142 pp. Editio Akademiae Scientiarum RSS UCR, Kioviae.

García Criado M., Väre H., Nieto A., Bento Elias R., Dyer R., Ivanenko Y., Ivanova D., Lansdown R., Antonio Molina J., Rouhan G., Rumsey F., Troia A., Vrba J. \& Christenhusz M. J. M. 2017. European Red List of Lycopods and Ferns. iv+59 pp. Brussels, Belgium, IUCN.

Gierczyk B., Kujawa A. \& Wójtowski M. 2007. Nowe stanowisko Botrychium matricariifolium (Ophioglossaceae) w środkowej Wilekopolsce. Fragm. Flor. Geobot. Ser. Polonica 14(1): 159-166.

Gilman A. V. 2003. Botrychium lunaria (L.) Swartz (Moonwort). Conservation and Research Plan for New England. 19 pp. New England Wild Flower Society, Framingham, Massachusetts.

Grulich V. 2012. Red List of vascular plants of the Czech Republic: 3rd edition. Preslia 84: 631-645.

Hultén E. \& Fries M. 1986. Atlas of North European vascular plants. North of the Tropic of Cancer. I-III. xvi+1172 pp. Koeltz Scientific Books, Königstein.

Jalas J. \& Suominen J. (eds.). 1972. Atlas Florae Europaeae. Distribution of Vascular Plants in Europe. 1, Pteridophyta (Psilotaceae to Azaollaceae), $121 \mathrm{pp}$. The Committee for Mapping the Flora of Europe \& Societas Biologica Fennica Vanamo, Helsinki.

Johnson-Groh C. 1998. Population demographics, underground ecology and phenology of Botrychium mormo.
In: N. Berlin, P. Miller, J. Borovansky, U. S. Seal \& O. Byers (eds.). Population and Habitat Viability Assessment Workshop for the Goblin Fern (Botrychium mormo): Final Report. CBSG, Apple Valley, MN.

KagAlo O. O. \& CHORNEY I. I. 2009. Botrychium virginianum (L.) Sw. In: YA. P. Didukh (ed.). Red Data Book of Ukraine. Vegetable kingdom, p. 37. Globalconsalting, Kyiv (in Ukrainian).

Kaźmierczakowa R., Zarzycki K. \& Mirek Z. (eds.). 2014. Polish Red Data Book of Plants. Pteridophytes and flowering plants. 895 pp. Polska Akademia Nauk, Instytut Ochrony Przyrody, Kraków.

Kaźmierczakowa R., Bloch-OrŁowska J., Celka Z., Chener A., Dajdok Z., Michalska-Hejduk D., Pawlikowski P., Szczę́́niak E. \& Ziarnek K. 2016. Polish red list of pteridophytes and flowering plants. 44 pp. Instytut Ochrony Przyrody Polskiej Akademii Nauk, Kraków.

Kish R. Ya., Danyluk I. M. \& Proc B. G. 2005. New findings of rare species of vascular plants on the Pritysyan Lowland (Transcarpathia, Ukraine). Scientific Bulletin of Uzhgorod University. Series Biology 16: 22-26 (in Ukrainian).

Klimov O. V., Vovk O. H., Filatova O. V., Hrama V. M., Podoba I. M., Ulanovskyi M. S., Klimov D. O., Fursova T. M., Nadtochyi H. S. \& Tveretynova V. V. 2005. Nature Conservation Lands of Kharkivska oblast'. 142-143 p. Raider, Kharkiv (in Ukrainian).

Klimuk Yu. V., Mitskevich Yu. D., Yakushenko D. M., ChoRney I. I., Budzhak V. V., Nyporko S. O., Shpilchak M. B., Chernyavski M. V., Tokaryuk A. I., Olexiv T. M., Tymchuk Ya. Ya., Solomakha V. A., Solomakha T. D. \& MAYOR R. V. 2006. Nature Zapovednik Gorgany: plant life. Pryrodno-zapovidni territoriyi Ukrainy. Roslynny svit, 6, 325 pp. Phytosociocentre, Kyiv (in Ukrainian).

KLOKov M. V. 1924: About northern plant cover in the southern-eastern part of Kharkivska oblast`. Botan. Zhurn. AN URSR 2: 40-41 (in Russian).

KRINITSIN I. G. 2004. Ontogenesis and the structure of populations of sporophytes of some species of Botrychium Sw. in Southern Taiga and Sub-Taiga of the European part of Russia. PhD Thesis in Biology. 19 pp. Barnaul (in Russian).

Krinitsin I. G. 2008. Polyvariance of the ontogeny of the sporophyte of the grower of the common moonwort Botrychium lunaria (L.) Sw. and its influence on the structure of cenopopulations of the species in the flora of subzones of the southern taiga and podtaiga of European Russia Actual problems of botany and ecology. Collection of scientific manuscripts 2: 87-93. Kyiv (in Russian).

KUCHEREVSKI V. V. 2001. The atlas of infrequent and vanishing plants of Dnepropetrovsk region. 360 pp. Phytosociocentre, Kyiv (in Ukrainian).

Kujawa A., GoŁdyn H., Arczyńska-Chudy E. 2005. A new locality of daisy leaf grape fern (Botrychium matricariifolium) in western Poland. Rocz.AR Pozn. 372, Bot.-Stec. 8: 129-132.

KuZMinsKa O. B. 2006. Study of the vegetation around camp Lunka in Krasnoyilske forestry, Chernihivska oblast` 
- scientific work on Ukrainian Small Academy of Science competition. 44 pp. Chernivtsi (in Ukrainian).

Laskowska-Ginszt A. \& WoŁkowycki M. 2012. Nowe stanowisko Podejźrzona rutolistnego Botrychium multifidum w Puszczy Białowieskiej. Przegląd Przyrodniczy 33(2): 86-90.

LAW OF Ukraine 2017. The Law of Ukraine on the Red Data Book of Ukraine, №3055. http://zakon3.rada.gov.ua/ laws/show/3055-14 (in Ukrainian).

Lellinger D. B. 1985. A Field Manual of the Ferns and Fern Allies of United States and Canada. Smithsonian Institution Press, Washington, D. C., USA.

Lukash O. V. 1997. Rare species of ferns (Polypodiophyta) in the rivers Desna-Oster. Ukr. Bot. J. 54(5): 461-465 (in Ukrainian).

Malynovsky K., Tsaryk Y., Kyyak V. \& Nesteruk Yu. 2002. Rare, Endemic, Relict plants and plants near the edges of their ranges in the Ukrainian Carpathians. 24 pp. Liha-Pres. L'viv.

Maslova V. R., Lesnyak L. I., Melnik V. I., Peregrym M. M. 2003. Red Data Book of Luhanska Oblast'. Vascular plants: Monography. 1-11 p. Znannya, Luhansk.

Matuszkiewicz W. 2001. Przewodnik do oznaczania zbiorowisk roślinnych Polski. In: J. B. FAliński (ed.). Vademecum Geobotanicum 3, 537 pp. Wyd. Nauk. PWN, Warszawa.

MĄDALSKi J. 1938. Botrychium virginianum Sw. na północnej krawędzi Podola. Kosmos, Ser. A 63(3): 363-375.

Melnik V. I. 1976. New sites for Huperzia selago (L.) Bemh. ex Schrank et Mart. and Botrychium multifidum (Gmel.) Rupr on Volyn Polesia. Ukr. Bot. J. 33(4): 401-402 (in Ukrainian).

MeLnik V. I. 2000. Rare plants of the forests on plains in Ukraine. 126 pp. Phytosociocentre, Kyiv (in Russian).

Melnik V. I. 2009. Species of genus Botrychium Sw. (Botrychiceae) recommended for inclusion in the Red Data Book of Ukraine: geographical distribution and population status. Scientific reports of NUKMA 93: 45-53 (in Ukrainian).

Meusel H., Jäger E. \& Weinert E. 1965. Vergleichende Chorologie der zentraleuropäischen Flora. I. Text 583 pp., Karten 258 pp. Gustav Fischer Verlag, Jena.

Moysiyenko I. I., Melnik R. P., Zakharova M. Ya, Sadova O. F. \& PARnikoza I. Yu. 2016. A new locality of Ophioglossum vulgatum on the lower Dnieper sands. In: Rare plants and fungi of Ukraine and adjacent areas: implementing conservation strategies. Proceedings of the 4rd International conference. Kyiv. 16-20 May 2016, pp. 103-105.

Montresor V. V. 1891. The review of plants belonging to the flora of the provinces of the Kyiv Academic District: Kyivska, Podolska, Volynska, Chernigovska and Poltavska, 4: 1-90 (in Russian).

Mosyakin S. L. \& Fedoronchuk M. M. 1999. Vascular plants of Ukraine a nomenclatural checklist. 346 pp. M. G. Kholodny of Botany, National Academy of Sciences of Ukraine.

Mотүка J. 1947. Rozmieszczenie i ekologia roślin naczyniowych na północnej krawędzi zachodniego Podola. Ann. Univ. Mariae Curie-Skłodowska Sect. C, Suppl. 3: $1-400$.
Muller S. 1993. Population dynamics in Botrychium matricariifolium in Bitcherland (Northern Vosges Mountains, France). Belg J Bot 126: 13-19.

Muller S. 1999. Plant communities and conservation of Botrychium-rich grasslands in the Bitcherland (Northern Vosges Biosphere Reserve, France): Biodivers Conserv 8(11): 1519-1532.

Muller S. 2000. Assessing occurrence and habitat of Ophioglossum vulgatum L. and other Ophioglossaceae in European forests. Significance for nature conservation. Biodivers Conserv 9(5): 673-681.

NAKonechny O. M. 2007. The composition of the vegetation with Ophioglossum vulgatum in Holytsky zakaznik on Opilliya. Riznomanittya fitobioty: shlyakhy vidnovlennya, zbahachennya i zberezhennya. Istoriya ta suchasni problemy. Materialy mizhnarodnoi konferentsii, prysvyachenoi 200-prichchu zasnuvannya Kremenetskoho botanichnoho sadu. 176-177 p. Kremenets', Ternopil' (in Ukrainian).

Notov A. A. 2002a. Botrychium matricariifolium A. Br. ex Koch. In: A. S. Sorokin (ed.). Red Data Book of Tver Oblast, pp. 37-38. Veche Tveri Antiek, Tver.

Notov A. A. 2002b. Botrychium virginianum (L.) Sw. In: A. S. Sorokin (ed.). Red Data Book of Tver Oblast, pp. 37. Veche Tveri Antiek, Tver.

NowaK S. \& NowaK A. 2008. A new locality of Botrychium matricariifolium (Retz.) A. Baraun ex W. D. J. Koch in the Sudeten Foreland. In: E. SzCZĘŚNIAK \& E. GolA (eds.). Club mosses horsetails and ferns in Poland recourses and protection. 205-212 pp. Polish Botanical Society \& Institute of Plant Biology, University of Wrocław.

OBerdorfer E. 1994. Pflanzensoziologische Exkursionsflora. 7. Auflage. 1050 pp. Ulmer Verlag, Stuttgart.

Olejnik N. \& Celka Z. 2015. The Growth Pattern of Ophioglossoid Ferns: A Case Study of Botrychium lunaria (L.) Sw. Am Fern J 105(3): 199-210.

Onyshchenko V. A. \& Andrienko T. L. 2012a. Phytodiversity of nature reserves and national nature parks of Ukraine. P. 1. Biosphere Reserves. Nature reserves. 406 pp. Phytosociocentre, Kyiv (in Ukrainian).

Onyshchenko V. A. \& Andrienko T. L. 2012b. Phytodiversity of nature reserves and national nature parks of Ukraine. P. 2. National nature parks. 580 pp. Phytosociocentre, Kyiv (in Ukrainian).

Orlov O. O., Sirenky S. P., Podobaylo A. V. \& Sesin V. A. 2001. Nature Reserved Lands of Zhytomirska Oblast. 196 pp. Phytosociocentre, Kyiv (in Ukrainian).

Orlov O. O. \& YaKushenko D. M. 2005. Vegetation of the projected Korostyshivsky National Park. 25 pp. Phytosociocentre, Kyiv (in Ukrainian).

Panchenko S. M. 2005. Flora of the National Park Desnyansko-Starohutsky and the problems of preserving the phytodiversity of Novhorod-Siverske Polissiya: Monograph. 170 pp. VTD Universytetska knyha Sumy (in Ukrainian).

PARfiEnOV V. I. (ed.). 2009. Flora of Belarus. Vascular Plants 1, 264 pp. Belaruskaya Nauka, Minsk (in Russian).

PARNIKOZA I. Yu. 2002. A finding of Botrychium matricariifolium A. Br. ex Koch in the Middle Dnipro Region. Ukr. Bot. J. 6: 289-295 (in Ukrainian). 
PARNIKOZA I. Yu. 2010. Modern state of Ophioglossaceae species of flora of Ukraine. Zapovidna Sprava v Ukraine 1: 22-27 (in Ukrainian).

Parnikoza I. Yu. 2012. Ophiglossum vulgatum L. in the Dnipro Valley in Kyiv. In: I. ZAGORODNIUK (ed.). Dynamics of biodiversity: Collection of scientific papers, 69-73 pp. Lugansk National University of Taras Shevchenko (in Ukrainian).

Parnikoza I. Yu. 2015. Moonwort (Botrychium lunaria (L.) Sw.) on the North Slope of Alaska. Actual problems of botany and ecology. Materials of international conference of young scientist in honor of 120 anniversary of born of D. Zerov. Poltava, 15-20.09.2015. 81-82 p.

Parnikoza I. Yu. \& Celka Z. 2016a. An archive of the Ophioglossaceae findings in Ukraine. In: Rare plants and fungi of Ukraine and adjacent areas: implementing conservation strategies. Proceedings of the 4rd International conference. Kyiv. 16-20 May 2016, pp. 119-125.

Parnikoza I. Yu. \& Celka Z. 2016b. Botrychium simplex E. Hitchc. (Ophioglossaceae) - a new species for the native flora of Ukraine. Biodiv. Res. Conserv. 43: 7-12.

Parnikoza I. Yu. \& Cukanova A. O. 2005. Condition of the Botrychium multifidum (S. G. Gmel.) Rupr. cenopopulations in the Kyiv territory. Ukr. Bot. J. 62(2): 289-295 (in Ukrainian).

Parnikoza I. Yu. \& HilchuK P. V. 2002. A survey of coenopopulations of rare and disappearing plants in the Rakhivsky region of Transcarpathia. Zapovidna sprava v Ukraini 8(1): 35-39 (in Ukrainian).

Parnikoza I. Yu. \& Krinitsin I. G. 2014. Botrychium virginianum (L.) Sw. populations in Pennsylvania (USA) and Kostroma region (Russia). The Plant Kingdom in the Red Data Book of Ukraine: Implementing the Global Strategy for Plant Conservation. Proceedings of III International Conference (4-7 june 2014, Lvyv), 137-141 p. Lviv (in Russian).

Parnikoza I. Yu. \& Shevchenko M. S. 2009. The ferns of Ophioglossaceae on area of Kyiv city. II International scientific-practical conference Young scientists - for botanical science 2009, 24-25 September 2009. 158-162 pp. Homel F. Skoryna State University (in Belarusian).

Parnikoza I. Yu., Shevchenko M. S., Inozemtseva D. M., VAsylyuk O. V. \& Shevchenko O. S. 2008. Rare flora: conservation, research, reintroduction. 132 pp. KECC Kyiv (in Ukrainian).

PAWLIKOWSKi P. 2011. Botrychium virginianum (Ophioglossaceae) rediscovered in Poland. Polish Bot J 56(1): 81-84.

Pawlikowski P. 2014. CR Botrychium virginianum (L.) Swartz, Podejźrzon wirginijski. In: R. KAźMIERCZAKowa, K. ZARZYCKI \& Z. MireK (eds.). Polish Red Data Book of Plants. Pteridophytes and flowering plants, wyd. III uaktualnione i rozszerzone, pp. 49-51. Polska Akademia Nauk, Instytut Ochrony Przyrody, Kraków.

Piękoś-Mirkowa H., Kwolek T. \& Kościelniak R. 2008. DD Podejźrzon rutolistny Botrychium multifidum (S. G. Gmel.) Rupr. In: Z. Mirek \& H. PięKoś-Mirkowa (eds.). Czerwona Księga Karpat Polskich. Rośliny naczyniowe, 39-41 pp. Instutut Botaniki im. W. Szafera PAN, Instytut Ochrony Przyrody PAN, Kraków.

Pięroś-Mirkowa H. \& Mirek Z. 2006. Flora Polski. Rośliny chronione. 418 pp. Multico Oficyna wydawnicza, Warszawa.

Popovych S. Yu. (ed.). 2002. A list of rare biodiversity of zapovedniks and national parks of Ukraine - phyto-, myco-, and phytocoenological stocks. 276 pp Phytosociocentre, Kyiv (in Ukrainian).

ProcházKa F. (ed.) 2001. Black and Red List of Vascular Plants of the Czech Republic - 2000. Píroda, Praha, 18: 1-166. http://portal.nature.cz/publik_syst/files/ RL_OP18_cevnt.pdf (in Czech).

Prokudin Yu. N., Dobrochaeva D. N., Zaverukha B. V., Chopik V. I., Protopopova V. V. \& Kritskaya L. I. (eds.). 1987. Identification Key of Vascular Plants of Ukraine. 548 pp. Phytosociocentre, Kyiv (in Ukrainian).

Prokudin Yu. N., Dobrochaeva D. N., Zaverukha B. V., Chopik V. I., Protopopova V. V. \& Kritskaya L. I. (eds.). 1999. Identification Key of Vascular Plants of Ukraine. 548 pp. Phytosociocentre, Kyiv (in Ukrainian).

PryadKo O. I. 2004. Coenotic and floristic diversity of the Mezhyrichenski RLP (Chernihivska region). Visnyk zaporizkoho derzhavnoho universytetu 1: 190-195 (in Ukrainian)

Pryer K. M., E. Schuettpelz, P. G. Wolf, H. Schneider, A. R. Smith, And R. Cranfill. 2004. Phylogeny and evolution of ferns (monilophytes) with a focus on the early leptosporangiate divergences. Am J Bot 91: 1582-1598.

RAŠOMAVIČIUS V. (ed.). 2007. Red Data Book of Lithuania. 799 pp. Lututé, Publishing Company.

Rubtsov N. I (ed.). 1972. The key to the higher plants of the Crimea. 552 pp. Nauka, Leningrad (in Russian).

RudenKo M. I. 2007. Rare species of plants of the Crimean nature zapovednik. Zapovedniks of Crimea. Matherials of IV international scientific-practical conference. Vol. 1, 133-144 pp. Botany. General questions of nature protecton. Simferopol (in Russian).

Rudenko M. I. 2015. Botrychium lunaria (L.). Swartz. In: A. V. YenA \& A. V. FAteryga (eds.). Red Data Book of the Republic of Crimea. Plants, algae and fungi, p. 46. PP “ARIAL” LLC Simferopol (in Russian).

Schmalhausen I. F. 1891. About some plants species new for Kyiv vicinities. Zapisky Kyevskogo Obshestva Estestvoispytatelei 11: 69-74 (in Russian).

Schmalhauzen I. F. 1897. Flora of Central and South Russia, Crimea and Northern Caucasus. V.2 752 pp. Kyiv (in Russian).

Sheleheda V. I. \& Rastvorova V. O. 2007. Diversity and distribution of Polypodiopsida on and near Khortytsya Island - Abstract Book of International confernece "Modern problems of biology, ecology and chemistry" in honor to 20-anniversary of biological department of Zaporizia National University. Zaporizhzhya 106-108 pp. (in Russian).

Shevchyk V. L., Solomaha V. A. \& Voytyuk V. O. 1996. Syntaxonomy of the vegetation and checklist of flora of Kanivsky nature zapovednik. Ukr. Fitocen. Zb. Seria B, 1: 1-119 (in Ukrainian). 
Sichak N. M., Melnik V. I., Lukash O. V. \& Panchenko S. M. 2009. Botrychium multifidum (S. G. Gmel.) Rupr. In: Ya. P. Didukh (ed.). Red Data Book of Ukraine. Vegetable kingdom, p. 36. Globalkonsalting, Kyiv (in Ukrainian).

Sirotina M. V., Krinitsyn I. G., Zontikov D. N. \& Parnikoza I. Y. 2014. Analysis and suggestions on monitoring of the population of Botrychium virginianum (L.) Sw. in remote parts of the geographical range (based on the examples of Pennsylvania (USA) and Kostroma region (Russia). Advanced Materials Research 955959: 1267-1271. doi:10.4028/www.scientific.net/ AMR.955-959.1267

Smith A. R., Pryer K. M., Schuettpelz E., Korall P., Schneider H. \& Wolf P. G. 2006. A classification for extant ferns. Taxon 55(3): 705-731.

STÅnL P. 1998. The establishment of Botrychium virginianum in a forest clearing in Gastrikland, central Sweden. Svensk Botanisk Tidskrift. 92(2): 81-82.

Stetsenko N. M. 2000. Family of Ophioglossaceae (R. Br.) Agardh in the exhibition "Spore Plants" of the O. V. Fomin botanical garden. Bulleten Kyivskogo Nacionalnogo Universytetu im Tarasa Shevchenka 30: 53-54 (in Ukrainian).

SzCZĘŚNIAK E. 1998. Nowe stanowisko Botrychium matricariifolium (Ophioglossaceae) na Dolnym Śląsku. Fragm. Flor. Geobot. Ser. Polonica 5: 301-316.

SzCZĘŚNIAK E. 2002. Podejźrzon marunowy Botrychium matricariifolium (Retz.) A. Braun ex W. D. J. Koch. In: A. NowaK \& K. Spalek (eds.). Czerwona Księga Roślin Województwa Opolskiego. Rośliny naczyniowe wymarłe, zagrożone i rzadkie, p. 90. Opolskie Towarzystwo Przyjaciół Nauk, Śląskie Wydawnictwo ADAN, Opole.

Szcześniak E. \& TlaŁka D. 2014. CR Botrychium matricariifolium (Retz.) A. Braun ex W. D. J. Koch., Podejźrzon marunowy. In: R. KAźmierczaKowa, K. Zarzycki \& Z. Mirek (eds.). Polish Red Data Book of Plants. Pteridophytes and flowering plants, wyd. III uaktualnione i rozszerzone, pp. 43-45. Polska Akademia Nauk, Instytut Ochrony Przyrody, Kraków.

SzCZęŚSIAK E., WÓJCIAK H. \& Tląka D. 2014. CR Botrychium multifidum (S. G. Gmeliln) Rupr., Podejźrzon rutolistny. In: R. KAźmierczaKowa, K. ZARZYCKI \& Z. MireK (eds.). Polish Red Data Book of Plants. Pteridophytes and flowering plants, wyd. III uaktualnione i rozszerzone, pp. 47-49. Polska Akademia Nauk, Instytut Ochrony Przyrody, Kraków.

Taseinkevich L. O. 2009. Botrychium matricariifolium (Retz.) A. Braun ex Koch - a new species for the flora of Chernivtsi region. Biological Systems. Naukovyi Visnyk Chernivetskoho Universytetu: Zbyrnyk Naukowych Prac 1(1): 91-92 (in Ukrainian).

TALIEV V. 1913. Introduction to Botanical Research of the Kharkiv Province. 28 pp. Kharkiv (in Russian).

Tkachenko V. S., Didukh Ya. P., Henov A. P., Dudka S. P., Vasser M. F., Boyko M. F., Vyetroba Z. I., Navorotska I. L., Partyka L. Ya., Helyuta V. P., SMYk L. V., Tykhonenko Yu. Ya., MerezhKo T. O., Burdyukova L. I. \& Soldatova I. M. 1998. The flora of Ukrainian
Steppe nature zapovednik. 232 pp. Phytosociocentre, Kyiv (in Ukrainian).

ToKariuk A. I. 2005. Ophioglossum vulgatum L. (Ophioglossaceae) in flora of Bukovina Prykarpat'a. 52-53 pp. Phytosociocentre, Kyiv (in Ukrainian).

Tzvelev N. N. 2004. About the genus Botrychium Swartz (Ophioglossaceae) in Russia. Novitates Systematicae Plantarum Vascularium 36: 7-21 (in Russian).

Tzvelev N. N. 2005. Problems of theoretical morphology and evolution of higher plants. 408 pp. KMK Scientific Press, Moscow-St. Petersburg (in Russian).

VAKhrusheVA L. P. 2015. Ophioglossum vulgatum L. In: A. V. YenA \& A. V. FAteryga (eds.). Red book of the Republic of Crimea. Plants, algae and fungi, p. 47. PP "ARIAL” LLC Simferopol (in Russian).

Vasheka O. V. \& Bezsmertna O. O. 2012. Ferns Atlas of Ukrainian Flora. 161 pp. Palyvoda, Kyiv (in Ukrainian).

Volodymyrets V. O. 2005. Species of higher vascular spore plants in the flora of Rivne region. Reports of National University of Water and Environmental Engineering. 2(30): 18-31. Rivne (in Ukrainian).

Voronova M.A. 1994. Palinostratigraphy of Lower Cretaceous and development of early cretaceous floras of Ukraine. 217 pp. Naukova Dumka, Kyiv (in Russian).

Votkalchuk K. A., Sanislo Ya. P. \& Bezsmertna O. O. 2014. Distribution of Botrychium matricariifolium (Ophioglossaceae) in Ukraine. Ukr. Bot. J. 71(6): 723-727 (in Ukrainian).

Voytyuk Yu. A., Bortnyak M. M., Shevchyk V. L. \& BAKalyna L.V. 1991. An annotated checklist of the vascular plants of the Kanivsky zapovednik. Flora i fauna zapovednikov SSSR 1-78 (in Ukrainian).

Wagner W. H. JR. 1962. Plant Compactness and Leaf production in Botrychium multifidum "ssp. typicum" and "forma dentatum". Am. Fern J. 52 (1): 1-18.

Wagner W. H. JR. \& Wagner F. S. 1993. Ophioglossaceae C. Agardh. Adder's-tongue Family. In: FNA Ed. Coмm. (eds.). Flora of North America, 2: 85-106. Oxford University Press, New York-Oxford.

Witkowski Z. J., Król W. \& Solarz W. (eds). 2003. Carpathian List of Endangered Species. xiii +64 pp. WWF International Danube-Carpathian Programme, Vienna, Austria; Institute of Nature Conservation, Polish Academy of Sciences, Kraków, Poland.

WoŁkowycki D. \& Pawlikowski P. 2008. Nowe stanowiska Botrychium multifidum (Ophioglossaceae) w dolinie Narwi i rozmieszczenie gatunku w województwie podlaskim. Fragm. Flor. Geobot. Ser. Polonica 15(1): 99-106.

Woziwoda B. \& WitosŁawski P. 2012. EN Botrychium lunaria (L.) Sw. In: R. Olaczek (ed.). Czerwona Księga Roślin Województwa Łódzkiego. Zagrożone rośliny naczyniowe. Zagrożone zbiorowiska roślinne, 32-33 pp. Ogród Botaniczny w Łodzi, Uniwersytet Łódzki, Łódź.

http://ww2.bgbm.org/EuroPlusMed/PTaxonDetail.asp?Name Cache $=$ Ophioglossum $\% 20$ azoricum $\&$ PTRefFk $=$

www.floraargentina.edu.ar

YAschenko P. T. 2007. Vegetation of Shatsky National Park. Naukovy Visnyk Volhynskoho derzhavnoho 
universytetu imeni Lesi Ukrainky 11(1): 166-171 (in Ukrainian).

ZaŁuski T. \& PAszek I. 2002 Stanowisko Botrychium multifidum (Ophioglossaceae) w Górznieńsko-Lidzbarskim Parku Krajobrazowym Fragm. Flor. Geobot. Ser. Polonica 9: 385-387.

Zarzycki K., Trzcińska-Tacik H., RóŻański W., Szeląg Z., WoleK J. \& KorzeniaK U. 2002. Ecological indicator values of vascular plants of Poland. In: Z. Mirek (ed.).
Biodiversity of Poland, 2, 183 pp. W. Szafer Institute of Botany, Polish Academy of Sciences, Kraków.

Żunowski W., Celka Z. \& OlejniK N. 2014. EX Botrychium simplex E. Hitchc. Podejźrzon pojedynczy. In: R. Kaźmierczakowa, K. Zarzycki \& Z. Mirek (eds.). Polska Czerwona Księga Roślin, Paprotniki i rośliny kwiatowe, wyd. III uaktualnione i rozszerzone, pp. 41-42. Polska Akademia Nauk, Instytut Ochrony Przyrody, Kraków. 